\title{
The role of the Protestant legacy in shaping Lower Silesian cultural heritage as exemplified by the refuge church in Borek Strzeliński (Großburg)
}

$$
\text { Janusz Łach - Alicja Krzemińska - Krzysztof Widawski - Anna Zaręba }
$$

Dr Janusz Łach

University of Wrocław

Faculty of Earth Sciences

and Environmental Management

Institute of Geography and Regional Development

pl. Uniwersytecki 1

50-137, Wrocław

Poland

e-mail: janusz.lach@uwr.edu.pl

ORCID: 0000-0001-8451-5957

Dr hab. Alicja Krzemińska

University of Wrocław

Faculty of Earth Sciences

and Environmental Management

Institute of Geography and Regional Development

pl. Uniwersytecki 1

50-137, Wrocław

Poland

e-mail: alicja.krzeminska@uwr.edu.pl

ORCID: 0000-0002-8410-4952
Dr hab. Krzysztof Widawski

University of Wrocław

Faculty of Earth Sciences

and Environmental Management

Institute of Geography and Regional Development

pl. Uniwersytecki 1

50-137, Wrocław

Poland

e-mail: krzysztof.widawski@uwr.edu.pl

ORCID: 0000-0001-6223-3860

Dr Anna Zaręba

University of Wrocław

Faculty of Earth Sciences

and Environmental Management

Institute of Geography and Regional Development

pl. Uniwersytecki 1

50-137, Wrocław

Poland

e-mail: anna.zareba@uwr.edu.pl

ORCID: 0000-0002-0291-7221

Muzeológia a kultúrne dedićstvo, 2022, 10:1:53-78

DOI: $10.46284 / \mathrm{mkd} .2021 .10 .1 .4$

The role of the Protestant legacy in shaping Lower Silesian cultural heritage as exemplified by the refuge church in Borek Strzelinski (Großburg)

Protestant refuge churches were built in Silesian Protestant principalities, and in the borderline areas of Saxony, Brandenburg and Poland before the end of Thirty Years' War and the signing of the Peace of Westphalia. In the most part, the churches were erected by means of adapting Catholic churches to the needs of Protestant believers, e.g. by building emporas (choir galleries), a pulpit and an altar inside the church. The acquisition of churches in Silesia was peaceful, without any violence almost everywhere, and it was not a rare phenomenon that a single church was used by two religions at the same time. At the end of the eighteenth century, there were approximately 110 refugee churches in Silesia. Currently, there are no churches of this type in Lower Silesia, and their extraordinary decoration was preserved in only a few of them. The main aim is to analyse this specific, forgotten sacral Protestent heritage, i.e. refuge churches in Lower Silesia, from the historical, sociological and architectural perspective. The main objective is to focus on the historical importance of the refuge churches in Lower Silesia - restoring identity as exemplified by the church in Großburg (Polish: Borek Strzeliński), analyse the degree to which the Protestant cultural legacy was preserved in the material rural architecture of Großburg and analyse the acceptance of the Evangelical heritage in the mentality of the local community.

Keywords: Lower Silesia, Borek Strzeliński (German: Großburg), refuge church, sacred landscape, Protestantism 
J. Lach et al.: The role of the Protestant legacy in shaping Lower Silesian cultural heritage as exemplified...

\section{Introduction}

This article, as indicated in the title, analyses the role of the Evangelical heritage in shaping the identity of Lower Silesia. In particular, it is based on Borek Strzeliński (German: Großburg), which excellently representats a situation typical of the whole area. Although one of the first regions where Protestantism developed, Lower Silesia, despite its complicated and often turbulent role in the history of Europe, is now somewhat off the beaten track. ${ }^{1}$ It is worth emphasising here the uniqueness of the church itself. Its story, as if through a lens, focuses the history of Protestantism throughout Central and Eastern Europe where it was not a passive witness to religious changes but a significant participant with great consequences. Its uniqueness, based on the cuius regio principle on the one hand, and the aspirations of the local community with a strongly embedded religious identity on the other, resulted from its location. The choice of the area, and more specifically the research subject, is not random. The Borek church was an important place for the development and implementation of the new ideas coming from Wittenberg which, a point worth emphasising, were adopted here voluntarily. This usually influences the viability of new ideas and indeed did so in this instance.

It is worth asking why this church should be worth a more thorough analysis. The temple in Borek, like many other "refuge" churches which were, according to the Treaty of Altranstädt, places of refuge for those who professed Protestantism in this part of Europe, is today something more. It is a kind of cultural legacy, despite all the changes through its complicated history, a silent witness to the rich but ambiguous history that remains in a landscape filled for three centuries with a German cultural heritage. ${ }^{2}$ This culture, which after the shock of World War II was at first rejected by those who had newly arrived, then distrustfully observed and adapted, has finally been in part accepted as part of the region's heritage. ${ }^{3}$ This heritage cannot be denied as it is still alive and undergoing constant transformation under the influence of contemporary residents (who are imposing their own history too but with an awareness of previous events) thanks to whom the region is still alive despite, or perhaps also because of, the heritage visible in the landscape.

\section{Refuge churches' history in the Lower Silesian Province}

The material heritage is exemplified by the Evangelical refuge churches that have been a part of the unique cultural heritage of Lower Silesia (Poland), although for many years they have been considered "post-German", and thus neglected or intentionally destroyed. The migrant population, poorly educated and driven by hatred towards anything "German" after the experience of war, were not interested in saving this heritage. As a result, many precious monuments have been destroyed or, as can be seen, are concealed by other uses; but now, with the engagement of academics and the managers of those assets, they are being discovered anew.

\footnotetext{
${ }^{1}$ See: PARUSHEV, Parush - PILLI, Toivo. Protestantism in Eastern Europe to the Present Day. In: Alister E. McGrath, Darren C. Marks (eds), The Blackwell Companion to Protestantism. Blackwell Publishing Ltd, 2004, pp. 155-160; and RYRIE, A. Protestants: The Faith That Made the Modern World. Viking, 2017. ISBN 14051574619781405157469. 2 See: HARRISON E. D. R. Lower Silesia from Nazi Germany to Communist Poland, 1942-49, German History, Volume 15, Issue 1, January 1997, p. 170-171. ISSN 0266-3554.

${ }^{3}$ See: BJORK, James - GERWATH, Robert. The Annaberg as a German-Polish Lieu de Mémoire, German History, Volume 25, Issue 3, July 2007, pp. 372-400. ISSN 0266-3554; and KARCH, Brendan. Germans to Poles: Communism, Nationalism, and Ethnic Cleansing after the Second World War, German History, Volume 32, Issue 2, June 2014, pp. 334-336. ISBN: 1107671485.
} 
There is a visible trend in social behaviour, including in its attitude towards "post-German" cultural heritage.

Evangelical refuge churches were designated in the Silesian Protestant principalities in the border areas of Saxony, Brandenburg and Poland before the end of the Thirty Years' War and the signing of the Peace of Westphalia in $1648 .{ }^{4}$ For the most part, these churches were established by adapting Catholic churches to the needs of Protestant believers, e.g. by building choir galleries, a pulpit and an altar. Such a takeover of churches in Silesia was peaceful almost everywhere without any violence, and it was not a rare phenomenon that a single church was used by two branches of Christianity at the same time.

Silesia was one of the first regions in Europe to be reached by ideas of reforming the Catholic Church, as formulated by Martin Luther. As early as 1518, i.e. a few months after Luther's speech in Wittenberg, in Nowy Kościół (Neukirch) near Złotoryja (Goldberg), a sermon with Reformation-related content was preached by Melchior Hoffmann. ${ }^{5}$ From 1526, in Silesia, then part of the Austrian Empire, a new Roman Catholic order was accepted by all principalities (the duchies of Legnica (Liegnitz), Brzeg (Brieg), Oleśnica (Oels), Bierutów (Bernstadt in Schlesien), Ziębice (Münsterberg), Cieszyn (Teschen) and Krnov (Fürstentum Jägerndorf)) i.e. those governed by rulers subject to the empire. In the remaining so-called imperial principalities (the duchies of Świdnica (Schweidnitz), Jawor (Jauer), Głogów (Glogau), Żagań (Sagan), Opole (Oppeln), and Racibórz (Ratibor)), the Evangelicals formed a majority even to 1635, and were able to remain so because of the arrangements of the Peace of Westphalia. ${ }^{6}$

An important phase in the history of Lower Silesia was the Thirty Years' War (1618-48) which brought about the destruction of Silesia and Lusatia. The majority of churches of both branches of Christianity were looted and demolished. In 1629, emperor Ferdinand II issued a restitution edict ordering the return of Catholic property taken over by Protestants who, because of the entry of the Swedish army led by Gustavus Adolphus into Silesia, had noticeably reanimated Protestantism. However, after the defeat of the Swedes in Lützen in 1632 where Gustavus Adolphus was killed, the commander of the army of the Austrian Empire, Albrecht von Wallenstein, started a brutal campaign to return the region to Catholicism. Under the Peace of Prague of 1635 , the restitution of property was postponed for nearly 40 years, although in all "imperial" principalities Protestants could choose between converting to Catholicism or

4 See: GRUNDMANN, Gunter. Der Evangelische Kirchenbau in Schlesien. Verlog Wolfgang Weidlich, Frankfurt am Main, 1970; and BANAŚ, Paweł. Studia nad śląską architekturą protestancką II połowy XVII wieku (Studies on Silesian Protestant architecture of the second half of the 17th century). Roczniki sztuki Ślaskiej. Muzeum Narodowe we Breslauiu, Breslau, 7, 1971, pp. 46-51. ISSN 0557-2231; and HARASIMOWICZ, Jan. Die Altranstädter Konvention und die Kunstlandschaft Schlesiens. In: Jürgen Wolf (ed.), 1707-2007 Altranstädter Konvention: Ein Meilenstein religiöser Toleranz in Europa, Halle (Saale): Sächsisches Staatsarchiv in Kommission bei mdv Mitteldeutscher Verlag, 2008 (Veröffentlichungen des Sächsischen Staatsarchivs, Reihe A: Archivverzeichnisse, Editionen und Fachbeiträge, Bd. 10), pp. 133-157. ISBN 978-3-89812-587-1.

5 See: SZCZEPANKIEWICZ-BATTEK, Joanna. Auf den spuren der Bomischen und Mahrischen bruder in Polen. Konsystosz Kościoła Ewangelicko-Reformowanego w RP, Warszawa, 2015a.

6 See: GOLIŃSKI, Mateusz, HARC Lucyna., MAROŃ Jerzy., WISZEWSKI Przemysław. Dolny Śląsk w latach 1526-1805 (Lower Silesia in the years 1526-1805). In: W. Wrzesiński (ed.), Dolny Ślask - monografia historyczna. Wyd. Uniwersytetu Breslauskiego, Breslau, 2006, pp. 261-296. ISBN: 83229-2763-0; and SZCZEPANKIEWICZ-BATTEK, Joanna. Kościoły graniczne i ucieczkowe w krajobrazie kulturowym pogranicza śląsko-łużyckiego i ziemi legnickiej (Border and refuge churches in the cultural landscape of the Silesian-Lusatian borderland and the Legnica region). Studia z. Geografii Politycznej i Historycznejm, vol.4, 2015b, pp. 291-311. ISSN 2450-0127; and CZAPLIŃSKI, Marek. Dzieje Śląska od 1806 do 1945 r. In: Czapliński M. (ed.), Historia Ślaska. Acta Universitatis Wratislaviensis, 3008, Wrocław, 2007, pp. 278-467. ISBN: 978-83-229-2872-1. 
J. Lach et al.: The role of the Protestant legacy in shaping Lower Silesian cultural heritage as exemplified...

leaving those territories within three years. Autonomy in religious matters was granted only to Wrocław (Breslau) and to the princes of Legnica (Liegnitz), Brzeg (Brieg) and Oława (Ohlau) who were Protestant. The Peace of Westphalia ${ }^{7}$ of 1648 supported the already-existing principle cuius regio, eius religio ${ }^{8}$ and, in effect, the Habsburg authorities in Silesia started to forcefully implement the rules of the counter-reformation under paragraphs 38-41 of article five. ${ }^{9}$ In the period 1648-54, the Evangelicals in Silesia lost 656 churches, 500 pastors ceased their work and the seized property included not only those churches that had been taken over at the time of the Reformation, but also those constructed by Protestants themselves. ${ }^{10}$ Under the Peace of Westphalia, the Habsburgs agreed to build three new Protestant churches in Lower Silesia, in the "imperial" principalities, known as the "Churches of Peace": Głogów-Glogau (1652), Jawor-Jauer (1654-55) and Świdnica-Schweidnitz (1656-57). An important episode in the history of the Protestant churches in Lower Silesia concerned the provisions of the Altranstädt convention in 1707 between King Charles XII of Sweden and Emperor Joseph I Habsburg. Once again, the Austrian Emperor agreed both to build six Protestant churches, the so-called "Churches of Grace" in Freystadt (Kożuchów), Sagan (Żagań), Militsch (Milicz), Hirschberg im Riesengebirge (Jelenia Góra), Landdeshut (Kamienna Góra) and Teschen (Cieszyn), and to the construction of border churches. It was a time of further adaptation of Catholic churches as refuge churches, for the needs of their own activities such as baptisms, weddings and funerals. After Silesia (with the exception of Cieszyn Silesia) was taken over by Prussia in 1740, thanks to the decision of the Prussian king Frederick II, there were equal rights for Catholics and Protestants in Silesia. ${ }^{11}$ The year 1740 marks the end of the function of refuge churches in Silesia; however, as Protestant churches, they survived until 1945. After World War II, the churches that found themselves in Poland were taken over by Catholics who refurbished them, in most cases in ways unrelated to their past. In the contemporary geography of the Protestant refuge churches of Lower Silesia in western Poland, two large clusters can be distinguished: the area along the Kwisa river valley (the former border between Prussia and Habsburg Silesia) and the area west of the city of Legnica (along the western border of the former Duchy of Legnica). A unique building with an unusual location in the central part of

\footnotetext{
7 The Peace of Westphalia is the collective name for two peace treaties signed in October 1648 in the Westphalian cities of Osnabrück and Münster. This marked the end of the Thirty Years' War and brought peace to the Holy Roman Empire, closing a calamitous period of European history that resulted in the death of approximately eight million people. Three treaties were signed to end each of the overlapping wars: the Peace of Münster, the Treaty of Münster, and the Treaty of Osnabrück. These treaties ended the Thirty Years' War (1618-1648) in the Holy Roman Empire, with the Habsburgs (rulers of Austria and Spain) and their Catholic allies on one side, fighting the Protestant powers (Sweden, Denmark and certain Holy Roman principalities) allied with France which was Catholic but strongly anti-Habsburg under King Louis XIV.

8 Cuius regio eius religio is a legal principle that regulates religious relations in a given territory, granting its ruler the right to determine its religion and ecclesiastical system. The principle was formulated by the Protestant lawyer J. Stephani, and was practiced in pre-Christian times, in antiquity and in the Middle Ages; later its intolerant character was revealed, especially in the Reformation era, when the Reich Seym in Augsburg (1555) legally allowed for the expulsion of those who refused to accept the ruler's religion (Peace of Augsburg); from the seventeenth century this rule was gradually relaxed, and in the eighteenth century it practically ceased to apply, being formally abolished in 1806 . ${ }^{9}$ CZAPLIŃSKI, Marek. Dzieje Śląska od 1806 do 1945 r. In Czapliński M. (ed.), Historia Ślaska. Acta Universitatis Wratislaviensis, 3008, Wrocław, 2007, pp. 278-467. ISBN: 978-83-229-2872-1.

${ }^{10}$ See: POPIOLEK, Kazimierz. Historia Ślaska od pradziejón do 1945 roku. Śląski Instytut Naukowy, 1984. ISBN 83216-0151-0.

${ }^{11}$ See: CZAPLIŃSKI, Marek. Dzieje Śląska od 1806 do 1945 r. In: Czapliński M. (ed.), Historia Ślaska. Acta Universitatis Wratislaviensis, 3008, Wrocław, 2007, pp. 278-467. ISBN: 978-83-229-2872-1.
} 


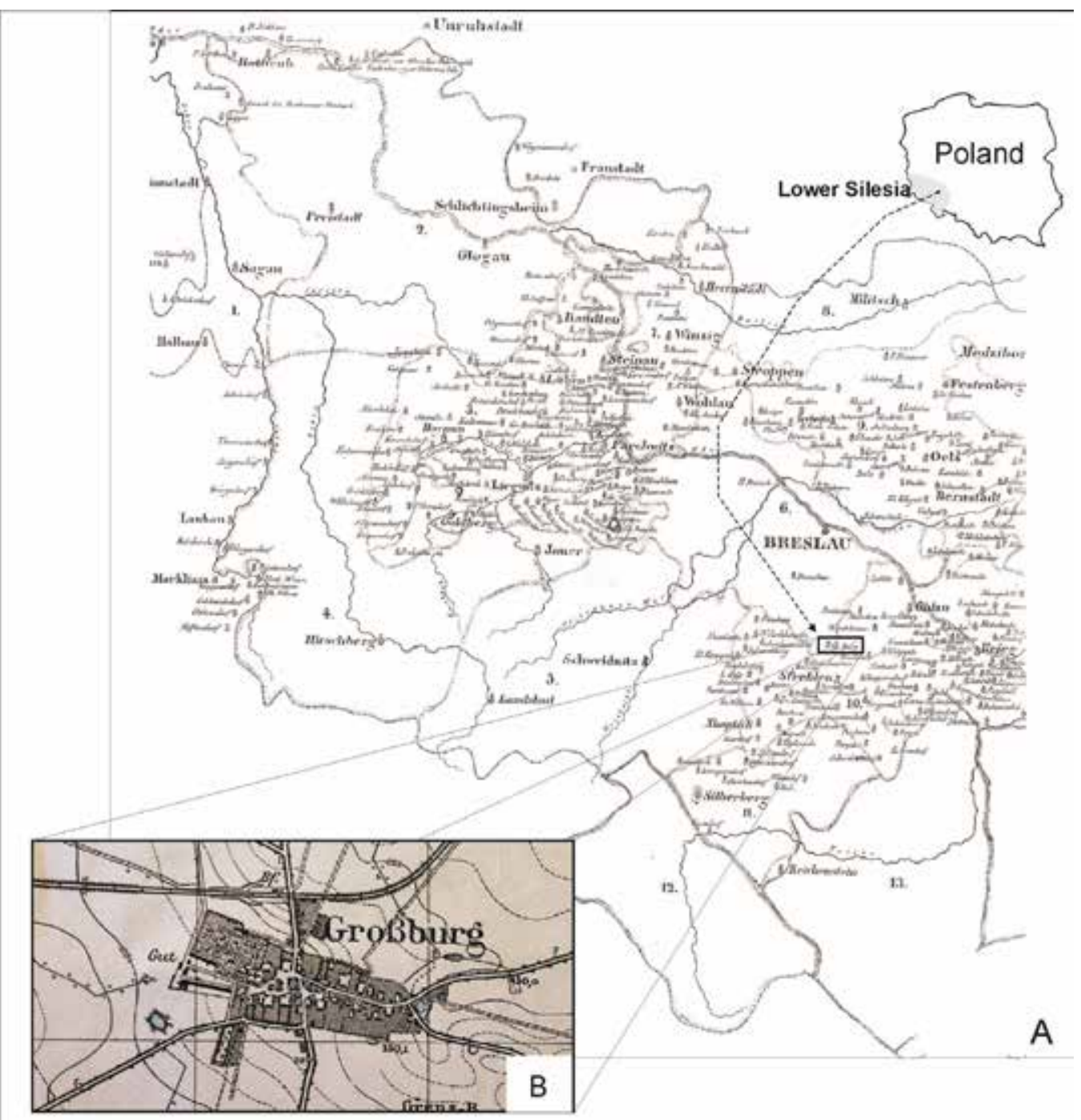

Fig. 1: The location of Protestant churches in Lower Silesia, including Borek Strzelinski (Großburg) Source: authors' elaboration: map A based on Das Evangelisch Scblesien in Folge der Altranstadtilchen Convention, 1707, by Edward Anders, in: Historischer Atlas der Evangelischen Kirchen in Scblesien, Glogau 1845; map B based on Messtischblatt kartenblatt Wäldchen, Breslau 1885

the Lower Silesia region, in the centre of the former Austrian Empire, is the former refuge church in Borek Strzeliński.

At the beginning of the eighteenth century, there were around 110 refuge churches ${ }^{12}$ (Fig. 1). Currently, in Lower Silesia, which is the western part of contemporary Silesia within the administrative borders of the Lower Silesian Voivodeship on Polish territory, the heritage of refuge churches has been preserved in a few buildings constituting a little-known historical and

\footnotetext{
${ }^{12}$ See: HARASIMOWICZ, Jan. Die Kunst der Reformationszeit als gemeinsames Kulturerbe an der mittleren Oder und unteren Warthe. In: Krystyna Gabryjelska and Ulrich Knefelkamp (eds), Brückenschläge. Kulturwissenschaften in Frankfurt (Oder) und Breslau. Vorträge der ersten gemeinsamen Ringvorlesung der Europa-Universität Viadrina Frankfurt (Oder) und der Universität Breslau. Berlin: scripvaz-Verlag Christof Krauskopf, 2000, pp. 31-45. ISBN 3931278131.
} 
religious phenomenon in the region. Among the preserved churches are those in Borek Strzeliński (Großburg) (Fig. 2), Krzywa (Kreibau) near Chojnów (Haynau), Twardocice (Harpersdorf),

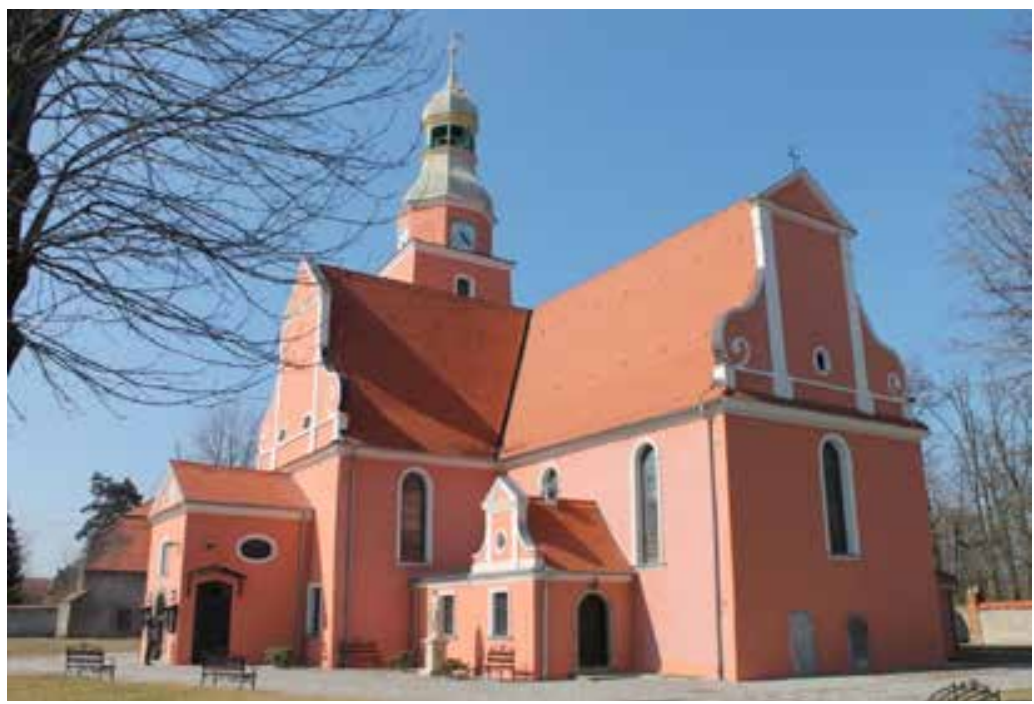

Fig. 2: Borek Strzelinski - the thirteenth century Church of St Lawrence \& St Anthony, originally and currently Roman Catholic

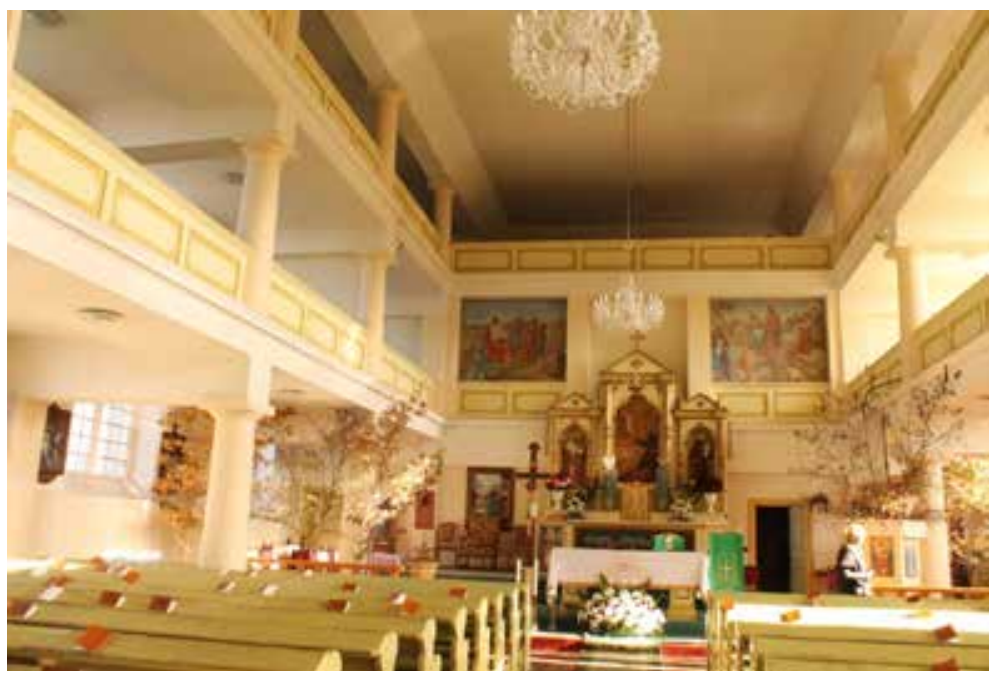

Fig. 3: Tomisław (Thommendorf) - Church of the Stigmata of St Francis of Assisi, currently Roman Catholic: preserved interior from the eighteenth / nineteenth centuries

Pielgrzymka (Pilgramsdorf), Proboszczów (Probsthain) and Nowa Wieś Grodziska (Neudorf aus Grödützberg) near Złotoryja (Goldberg), Kościelec (Hochkirch) near Legnica (Liegnitz), and twelve churches in the Kwisa valley, e.g. Tomisław (Thommendorf) (Fig. 3).

The twentieth century was a crisis period for the Protestant church in the former German territories. The Second World War and its final consequences contributed to the movement of the political borders of Central and Eastern European countries westwards. Thus, these territories of Eastern Germany came under Polish rule. 
The shifting of borders was accompanied by the process of the displacement of the German population with forced migration to the territories of Western Germany. ${ }^{13}$ The former population was replaced by migrants from central Poland, the Balkans and Kresy ${ }^{14}$ (today's Western Ukraine). ${ }^{15}$ The arrival of new inhabitants in these territories gave rise to a number of social, psychological, economic and cultural issues for the Christian religious legacy. ${ }^{16}$

Within the years that directly followed the war, a uniform social attitude was found whose unifying factor was hostility towards Germans. This was reflected in the (primitive) destruction of the tangible German heritage by the inhabitants together with local authorities and church elites. ${ }^{17}$ Visual symbols of German presence were removed since they were allegedly an open wound in the memory of the immigrant population and this was done on the initiative of the contemporary elites of the Polish People's Republic. Graveyards, monuments, inscriptions and epitaphs thus disappeared from urban and rural landscapes. ${ }^{18}$

It was only the political changes at the end of the twentieth century related to the collapse of the Soviet Union that led to countries behind the "Iron Curtain" mentally opening up to the world. Areas that for decades had been isolated from an international worldview by the imposition of a one-sided social stance, a mainly Marxist philosophy, shook off the stagnation and introduced economic and social changes. The dynamic changes in western Poland (in the former German territories) were accompanied by a change in approach to historical and cultural heritage, especially among the second and third generations. The introduction of lessons in regional education at the turn of the twenty-first century, and through the implementation of social and academic projects of social activation, meant that the inhabitants began to discover the rich historical and cultural heritage of these areas. There is a noticeable trend of looking for historical roots that allow individual identity to be defined, and to shape it in relation to the past without lying about it. In order to deepen this, the author analyses social attitudes towards the post-German heritage, in particular the material religious heritage of the Lower Silesia region.

\footnotetext{
${ }^{13}$ The process of forced migration concerned over 8 million Germans after 1945. It was a very difficult social process because it was accompanied by physical and mental distress. Despite the homogeneous ethnic and national structure, settlers from eastern Germany had problems with adapting to the population in the western part of Germany. For more detail, see: AHONEN, Pertti. On Forced Migrations: Transnational Realities and National Narratives in Post-1954 (West) Germany. In: German History, Vol. 32, No. 4, 2014, pp. 599-614. ISSN 0266-3554.

${ }^{14}$ Kresy Wschodnie (Kresy) was a term coined for the eastern part of the Second Polish Republic during the interwar period (1918-1939). Largely agricultural and extensively multi-ethnic, it amounted to nearly half of the territory of pre-war Poland. Historically situated in the eastern Polish-Lithuanian Commonwealth, following the eighteenth-century foreign partitions it was annexed by Russia and partly by the Habsburg Monarchy (Galicia), and ceded back to Poland in 1921 after the Peace of Riga. As a result of the post-World War II border changes, none of the Kresy lands remain in Poland today.

${ }^{15}$ See: JUREK Piotr. Osadnicy polscy w latach 1945-1947 (Polish settlers in 1945-1947). In: B. Cybulski (ed.), Dolny Ślask 1945 - Dolny Ślask 2005. Stowarzyszenie na Rzecz Promocji Dolnego Ślaska, Breslau, 2006, pp. 82-90. ISBN 8392325508 .

${ }^{16}$ See: CZARNUCH, Zbigniew. Oswajanie krajobrazu. Polscy osadnicy w dorzeczu dolnej Warty (Taming the landscape: Polish settlers in the Lower Warta basin). In: Mazur Z.(ed.), Wokót niemieckiego dziedzictwa kulturowego na Ziemiach Pótnocnych i Zachodnich. Wyd. Instytutu Zachodniego, Poznań, 1997, pp. 169-190. ISBN 83-85003-87-8.

${ }^{17}$ See: MAZUR, Zbigniew. Das deutsche Kulturerbe in den polnischen West und Nordgebieten (Studien der Forschungsstelle Ostmitteleuropa an der Universität Dortmund, Band 34). Wiesbaden, Harrassowitz Verlag, 2003. ISBN: 9783447048002; and ZYBURA, Marek. Der Umgang mit dem deutschen Kulturerbe in Schlesien nach 1945. Senfkorn-Verlag Theisen, Görlitz, 2005. ISBN 3-935330-19-7.

${ }^{18}$ See: ZYBURA, Marek. Polacy wobec niemieckiego dziedzictwa kulturowego na Dolnym Śląsku (Poles and German cultural heritage in Lower Silesia). In: B. Cybulski (ed.), Dolny Ślask 1945 - Dolny Ślask. 2005. Stowarzyszenie na Rzecz Promocji Dolnego Śląska, Breslau, 2006, pp. 257-271. ISBN 8392325508.
} 
J. Lach et al.: The role of the Protestant legacy in shaping Lower Silesian cultural heritage as exemplified...

\section{Characteristic features of seventeenth- and eighteenth-century protestant churches' architecture in the Lower Silesian Province}

The Protestant Silesian architecture of the second half of the seventeenth and eighteenth centuries developed a separate type of construction in terms of spatial layout and architectural forms. In sacred architecture, it had become important to group buildings intended for social purposes around the church, e.g. a parish house, a school, an orphanage or a cemetery. The number and function of the buildings resulted from the real needs of a given commune and the faithful who financed the investment. The spatial arrangement of sacred buildings, the architectural form of Protestant churches, and even their location were dictated by the complicated situation of the followers of Protestantism in Silesia. After the Thirty Years' War, in Silesia, which remained in the hands of the Habsburg Monarchy, there was a gradual restitution of Catholicism and the liquidation of the Protestant church structure. ${ }^{19}$ At the turn of 1650 and 1651, a recovery commission began operating, taking over Protestant churches, including new buildings built by Protestant communities. Relative religious freedom prevailed in the border areas of Silesia and at the borders of the Silesian duchies, where there were two types of churches: the so-called border churches (Grenzkirchen) and the so-called refuge churches (Zufluchtskirchen) - buildings owned by the commune, but made available to other believers. At the same time, on the basis of the Westphalian peace treaty of 1648 , the construction of the churches of Peace was started - in Świdnica, Jawor and Gogów.

Protestantism was characterised by a different attitude to church building, which adhered to simplicity of form and was primarily intended to create a place for proclaiming the Word of God. The result of the lack of a strong hierarchy in the church and the changed attitude towards the Eucharist was the liquidation of the presbytery as a separate part of the church serving as a sanctuary. In accordance with the canons of Protestant sacred architecture, church buildings should be well-lit, with a simple form and good acoustics. Due to the complicated geopolitical background of Silesia, sacred architecture developed in isolation from European Protestant architecture. Due to the difficult situation after the Thirty Years' War, border churches were built of wood in a skeleton structure. ${ }^{20}$ One of the first examples of such buildings was the church in Szliftyngowa near Wschowa, erected in the Polish-Lithuanian Commonwealth in 1644 by emigrants from Silesia fleeing religious persecution, built on a Greek cross plan. The transverse nave of the church was filled with a gallery floor, which allowed for the maximum use of the interior, while being the main decorative element of the interior. An exception among the border churches is the church in Biedrzychowice, originally built of wood, then rebuilt in the years 1723-1724 into a stone structure set on a rectangular plan with a polygonal presbytery and a high tower raised several times. Refuge churches, unlike border churches, were built in old church facilities adapted to the needs of Protestants, coming from various periods, but mostly from the Gothic. ${ }^{21}$ In the seventeenth and eighteenth centuries, their general modernisation began. Examples are the hall churches in Proboszczowo and Pielgrzymka with galleries running around the interior of the church on all four sides.

\footnotetext{
${ }^{19}$ See: KALINOWSKI, Konstanty. Barock in Schlesien. München, 1990. ISBN 3-422-06047-2.

${ }^{20}$ See: GORZELIK, Jerzy. Konsekwencje wojny trzydziestoletniej dla protestanckiego dziedzictwa artystycznego na Górnym Śląsku. In: Joachim Bahlcke, Wacław Gojniczek, Ryszard Kaczmarek (eds), Dziedziictwo górnoślaskiej reformacji. Wplyw protestantyzmu na polityke, społeczeństwo i kulture w wiekach XVI-XX. Katowice, 2018: Instytut Badań Regionalnych w Katowicach.

${ }^{21}$ See: KALINOWSKI, Konstanty. Barock in Schlesien. München, 1990. ISBN 3-422-06047-2.
} 
Specific guidelines regarding the principles for the erection of Protestant sacred buildings in Silesia were specified in the imperial permit for the construction of churches in Jawor and Świdnica. These were to be buildings erected outside the city walls, not of stone and brick, with a limited architectural form (the permit forbade the construction of church towers). The cheapness and universality of Protestant architecture were to be in contrast to the monumentalism of Catholic buildings erected in Habsburg Silesia. The first of the Peace churches was built in Głogów in 1651. The next one was the church in Jawor, erected in a skeleton-log structure designed by Albrecht Säbisch in the years 1654-1655. ${ }^{22}$ The church was built as a three-nave structure in the basilica system, with side aisles filled with galleries. In the western part, there is a two-story gallery with an organ. According to the Protestant ideology, the most important function of the church is to proclaim the Word of God; therefore the arrangement of the pews is subordinated to the pulpit located in the middle of the central nave. Another church was erected, also according to the design of Albrecht Säbisch in Świdnica, in the years 1656-1657. ${ }^{23}$ It was built on a Greek cross plan with a one-storey sacristy adjacent to the main body of the building from the east. The interior, as in the church in Jawor, is filled with galleries, with a pulpit located at the crossing of the arms. Decorative elements inside and outside of both churches are severely limited. Paradoxically, the magnificent, unprotected construction of the churches in Jawor and Świdnica, which are masterpieces of Silesian carpentry, have meant that both objects have been entered on the UNESCO World Heritage List.

\section{Research aim and methodology}

The subject of the research is the development of a unique resource for material heritage related to the Protestant religious architecture of rural areas in Lower Silesia, along with the spiritual values associated with those historical and moral phenomena that constitute the basis for the existence and functioning of a specific society. Regional identity, which includes personal and social identities, affects the preservation of cultural heritage, and thus the formation of a cultural image recorded in the landscape, as well as in its present use. ${ }^{24}$ In recent years, changes in the geographical environment of the rural area of Lower Silesia, a region with a specific historical, cultural and landscape heritage, have been seen. The "Recovered Territories" after World War II are currently undergoing social and cultural transformations which themselves are part of the heritage of the complex identity of its inhabitants. ${ }^{25}$ Observations carried out here reveal the scale of changes in lifestyle and rural culture as well as residential and commercial

\footnotetext{
${ }^{22}$ See: GRUK, Wojciech. Silesian Churches of Peace and the Royal Hungarian Articular Churches: Possible Legal and Architectural Relations. In: Protestantischer Kirchenbau der Frühen Neuzeit in Europa. Grundlagen und neue Forschungskonzepte - Protestant Church Architecture in Early Modern Europe: Fundamentals and New Research Approaches. Regensburg, 2015, pp. 333-343. ISBN 978-3-7954-2942-3.

${ }^{23}$ KALINOWSKI, Konstanty. Barock in Schlesien. München, 1990. ISBN 3-422-06047-2.

${ }^{24}$ See: LAMONT, Michèle - MOLNAR, Virág. The study of boundaries in the social sciences. In: Annual Review of Sociology, Vol. 28, 2002, pp. 167-195. ISSN 0360-0572; and BRUBAKER, Rogers - COOPER, Frederick. Beyond "identity". In: Theory and Society, Vol. 29, Issue: 1, 2000, pp. 1-47. ISSN 0304-2421; and SAM, David - BERRY John. Acculturation: When Individuals and Groups of Different Cultural Backgrounds Meet. In: Perspectives on Psychological Science, Vol. 5, Issue: 4, 2010, pp. 472-481. ISSN: 17456916; and see: SAM David - BERRY John. Acculturation: When Individuals and Groups of Different Cultural Backgrounds Meet. In: Perspectives on Psychological Science, Vol. 5, Issue: 4, 2010, pp. 472-481. ISSN: 17456916.

${ }^{25}$ See: BUKRABA-RYLSKA Izabella. Dziedzictwo kulturowe jako czynnik rozwoju obszarów wiejskich. In: Nurzyńska, I., Drygas, M. (eds), Rožwój obszarów wiejskich w Polsce. Diagnozyy, strategie, koncepcje polityki. Warszawa, IRWiR PAN, 2011, pp. 219-238. ISBN 83-89900-45-9.
} 
J. Lach et al.: The role of the Protestant legacy in shaping Lower Silesian cultural heritage as exemplified...

architecture. Generational change, and with it inward and outward migration, blurs the former lifestyle of the inhabitants. Therefore, it seems necessary to conduct research documenting the life and activity of the generation of displaced persons to maintain the continuity of cultural identity in the region. This is the last chance for a recording of the cultural heritage developed here, as both "moveable and immovable" aspects are without documentation.

For an analysis of the contemporary role of Protestant property, unknown and unique because of its history, the former Protestant refuge church in Borek Strzeliński was chosen as an interesting example of contemporary adaptation to the German historical heritage. The subject of the research is the former Protestant church in the village of Borek Strzeliński, which (as Großburg) in the seventeenth and eighteenth centuries had served as a refuge church ${ }^{26}$ during the re-Catholicization of Silesia.

In the article, the author puts forward two hypotheses:

- Is the refuge church in Borek Strzeliński unique, in terms of history, architecture and ecumenism, a sacrum of Catholic-Protestant origin, influencing social and landscape identity?

- Does the definition of the contemporary role of the Protestant sacrum in the landscape of the Lower Silesian countryside help to protect its unique heritage better?

The main objectives of the article are to:

- draw attention to the historical importance of refuge churches within Lower Silesia and their role in shaping the identity of its residents,

- study the degree to which the Evangelical heritage has been maintained in the sacred landscape of Borek Strzeliński and

- analyse the acceptance of the Evangelical heritage according to the age of the inhabitants of Borek Strzeliński, indicating which behaviours determine the identity of local cultural heritage.

In order to achieve the research objectives, the analysis and criticism of the literature, and the identification of distinctive architectural landmarks in material and spiritual space were the approaches used. ${ }^{27}$ One method was to search for Evangelical heritage artifacts in the field, as well as obtaining and analysing archival graphic documentation. A further important method was to conduct free sociological interviews: with Maria Czarnecka the sottys (village administrator), Wiesław Szczęch the priest, Elżbieta Sucharska the library director, and Sabina Zawer a librarian, along with a survey of the residents of Borek Strzeliński based on a sample of 275 in the summer of 2019. These methods enabled an inventory of the Evangelical heritage to be made and the attitude of the inhabitants to the German legacy after 74 years to be determined.

\footnotetext{
${ }^{26}$ Refuge churches - Evangelical churches located in Protestant areas (Duchy of Legnica, Lusatia) in the immediate vicinity of the re-Catholicised Silesia (under the Catholic authority of the Habsburgs). After the Thirty Years' War (1618-1648) in the seventeenth and eighteenth centuries, they served not only the local Evangelical population, but also additional believers from elsewhere who did not have religious freedom in their territories. The term “,refuge churches" refers to those churches that were built before the end of the war and the signing of the Peace of Westphalia, because churches that were built later to meet the needs of the increasing number of pilgrims from Silesia were called border churches. These churches ceased to fulfil their role in the 1840s, when Lower Silesia was occupied by Prussia. In the Prussian state freedom of religion prevailed, which allowed Silesian Protestants to celebrate religious services without having to make a pilgrimage abroad.

${ }^{27}$ See: MYCZKOWSKI, Zbigniew. Kompozycyjne i architektoniczne wyznaczniki tożsamości krajobrazów (Compositional and architectural determinants of landscape identity). In: Problemy Ekologii Krajobrazu, XL, 2015, pp. 199_ 208. ISSN: 1899-3850.
} 


\section{Borek Strzeliński refuge church architecture characteristic features}

The role of the history of the Protestant church, with the refuge church in Borek Strzeliński as an example of earlier and later religious episodes, is unique due to the architectural, pictorial and religious functions that influenced an increasing number of parishioners during this period. The beginning of the church in Borek Strzeliński should be associated with the year 1232 . At that time, a small chapel devoted to St Lawrence was erected in early Gothic style. Until the sixteenth century, the church, being a Catholic place of worship, was not subject to significant architectural change. A turning point was when, in 1537, the church came into the hands of the Evangelicals due to Friedrich von Kanitz of the Hohenzollerns taking over the estate of Borek. Later it became a refuge for persecuted Lutherans during the counter-reformation and was designated a refuge church. ${ }^{28}$ Between 1553 and 1579, the church was re-built in the Renaissance style and by 1579, the existing building had been extended by what is now a presbytery, the northern sacristy (currently St Anthony's Chapel) and a clock-and-bell tower (Fig. 4). Measuring more than 35 metres high, the square-shaped tower, topped by a Baroque helm, had a pointed-arch portal from 1250 on its southern wall, and a wooden door with fittings dating back to 1519. At the top of the tower, there are now two bells from different epochs in the history of the church. The first bell, from 1850, was a gift of the German parishioners; the second one, from 1964, was also funded by parishioners when the church was visited by the image of Our Lady of Częstochowa to celebrate the 1000th anniversary of Poland's baptism.

Since 1700 , due to the increasing number of parishioners seeking religious freedom, the

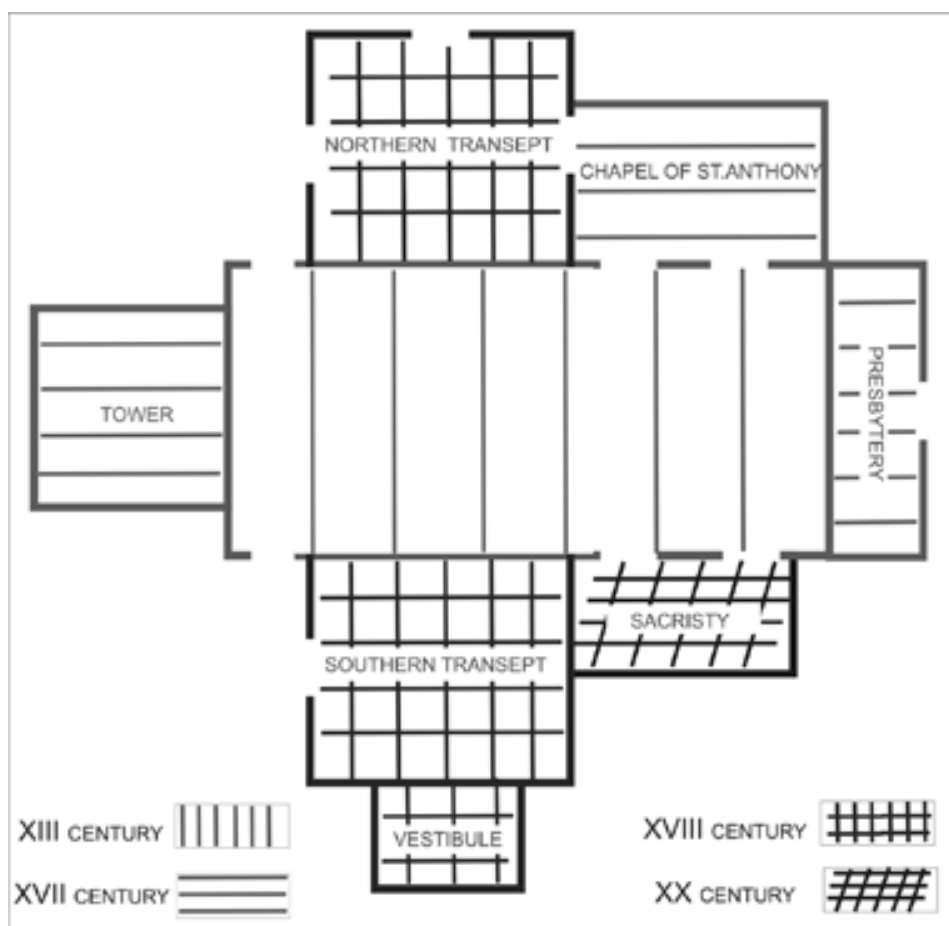
church has been expanded with a pictorial and sculptural splendour that is unusual for Protestant churches. In 1700, the northern and southern transepts were added, creating the form of a cross, while the southern aisle was expanded by a vestibule with outer stairs leading to a gallery (Fig. 4). General reconstruction from 1700-13, apart from changing the shape of the church, also involved its interior, in particular with the addition of the wooden, coffered

Fig. 4: A plan showing the extensions to the church through eight centuries

polychromatic ceiling, altar, pulpit with a canopy, church organ and galleries. The ceiling of St Lawrence \& St Anthony's Church, made by an unknown craftsman between 1702 and 1713,

\footnotetext{
${ }^{28}$ See: JAKUBOWICZ, Zbigniew. Osobliwości pogranicza Ziemi Otawskiej - Kościół ucieczkowy w Borku Strzelinskim (Singularities of the Oławska borderland - the refuge church in Großburg). Wiadomości Oławskie, 1997, p. 15.
} 
was divided into 32 coffers covered in tempera with a unique motif of acanthus leaves featuring different flowers (clover, rose or tulip) ${ }^{29}$ (Fig. 5).

Particular attention must be paid to the wooden galleries of 1702 which were decorated with biblical paintings, and located at the back of the church and over the side aisles. The galleries along the main aisle existed until 1954 when they were demolished (Fig. 6). With the galleries, the church could hold 2000 people at one time. The galleries that remain today are decorated with polychromes: Jesus' Baptism in the Jordan, the Holy Family at work, Christ's Transfiguration, the fight between David and Goliath, Christ in the Garden of Gethsemane, Moses raising the Bronze Serpent, Jonah emerging from the Belly of the Whale, Christ's Crucifixion, the Judgement of Solomon, and the Sermon on the Mount (Fig. 7). The galleries have coffered ceilings as well, and are supported on wooden, profiled columns. Above the chancel galleries there is a highly decorative organ screen from 1779, originally built by Michael Röder in 1735-36 (not existing today), and re-built between 1890 and 1912 by Schlag und Söhne from Świdnica (Schweidnitz). The organ screen is richly decorated with beautiful woodcarvings with plant elements and finished with a golden crown. The von Tenczin family, owners of Großburg (Borek Strzeliński), had the screen built between 1745 and 1796.

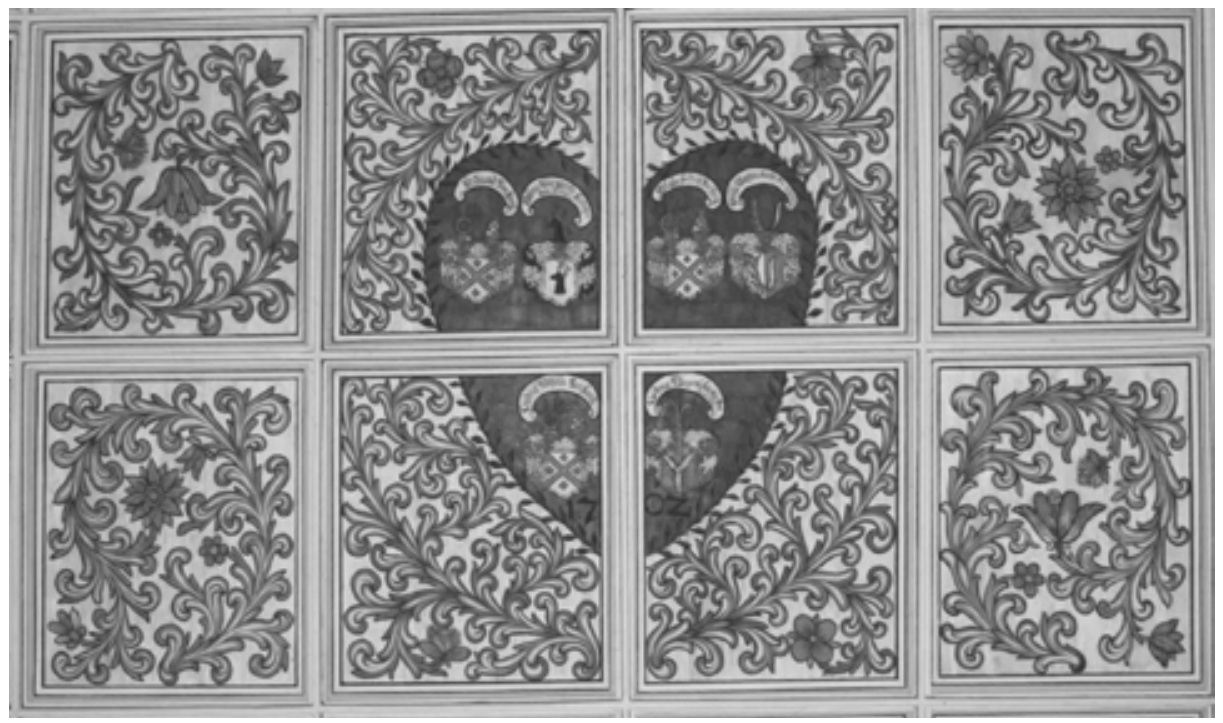

Fig. 5: A fragment of the church ceiling polychrome; in the centre can be seen the date of its painting1702

The richly decorated pulpit with images of the Evangelists - John (with an eagle), Luke (with an ox), Matthew (with an angel) and Mark (with a lion) - also dates to that period. The beautiful Baroque altar with an image of the Good Shepherd is from 1720. This altar, which is a single-axis, single-level construction with Corinthian columns, over which there is a wooden entablature with a sculpture dedicated to "The glory of the Holy Trinity", was made in the same year. On the sides of the altar there are sculptures from the 1920s depicting St Anthony

\footnotetext{
${ }^{29}$ See: GIBSKI Damian. Karta ewidencyjna zabytku architektury i budownictwa WOSOZ we Breslauiu ("Identification card" of the WOSOZ architectural and building monument in Breslau). N.d; and STEPIŃSKA, Maria. Dokumentacja konserwatorska malowideł drewnianego stropu kościoła p.w. Św. Św. Wawrzyńca i Antoniego w Borku Strzelińskim (Conservation documentation on the paintings on the wooden ceiling of the church of Sts Wawrzyniec \& Antoni in Großburg), Number inv. 9/02, Brzeg, 2002.
} 
of Padua and St Hedwig of Silesia while in the central part there is a painting by Pfannschmidt from 1873 depicting Christ as the Good Shepherd given by the von Schoenermarck family. Another renovation of the church took place in 1912-13 and involved the construction of the present sacristy. Within that period, Renaissance style graves from 1684-1750 commemorating Johann Sigmund von Kanitz und Dallwitz and Justina Maksymiliana von Kanitz were placed in the entrance (Fig. 8) and in the main aisle, and epitaphs to Johann Berger and Helen Eleonora Hochlin were placed on the northern part of the church wall. ${ }^{30}$ The beginning of the twentieth century was a time of much activity in a parish of around 4000 believers and its important role
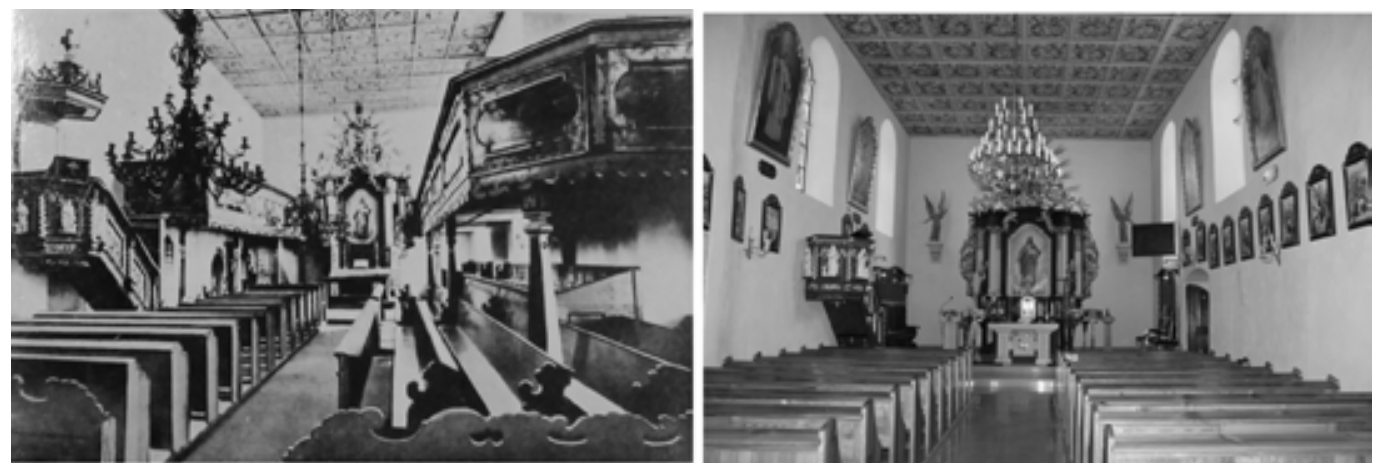

Fig. 6: The interior of the church in the early twentieth century (1912) and at present - the galleries visible in the earlier figure were demolished in 1954 along with the canopy over the pulpit
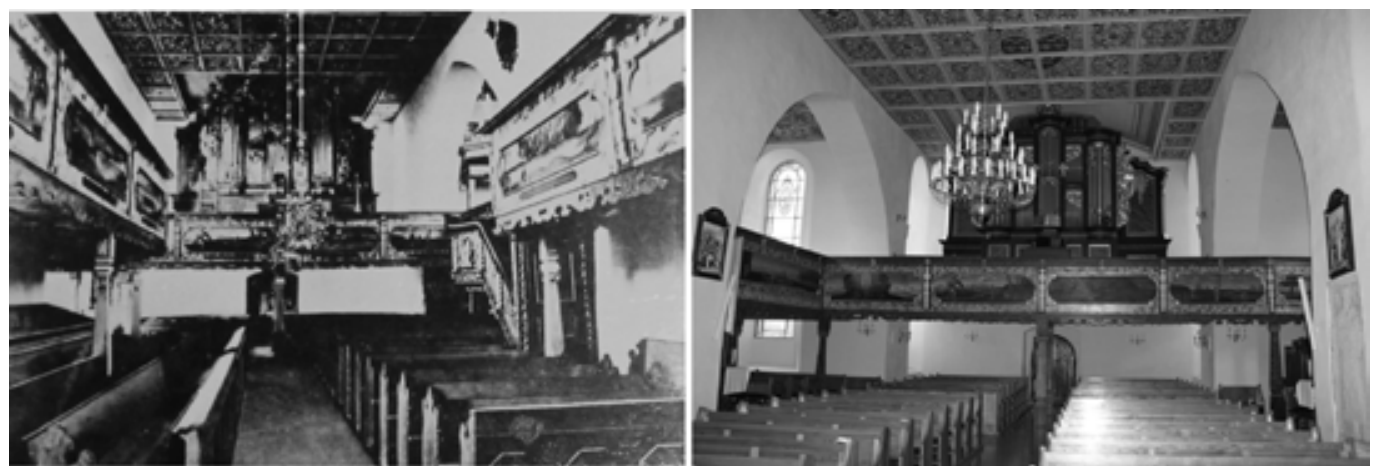

Fig. 7: The organ screen with galleries, early twentieth century and present

in the spiritual life of the region may be proven by dedicated prayers enriching the liturgy, as exemplified by the vespers specially written for the Großburg parish (Fig. 9).

After 1945, the church, together with its material and spiritual legacy, came into the possession of Polish communities from the east, and St Lawrence became again a Roman Catholic Church. Since 1952, with the consent of Cardinal Stephen Wyszyński, it has been the Church of St Lawrence \& St Anthony. The war caused much damage to the windows and church walls, and in 1952 it underwent its first renovation, allowing believers to participate once more in religious worship. After the demolition of the side galleries and the canopy over the pulpit in 1954, a

\footnotetext{
${ }^{30}$ See: DOBRZYNIECKI Aneta, et al. Powiat Strzeliński - Großburg (Poviat of Strzeliński - Großburg). In: Katalog Zabytów Sztuki Województwo Breslauskie (Dolnoślaskie (edit.) E. Kołaczkiewicz,). Wyd. Instytut Sztuki PAN Instytut Historii Sztuki Uniwersytetu Breslauskiego, Warszawa, 2008, pp. 9-19 ISBN 978-83-89101-47-1. Kronika parafialna 1946-2012, Parafia pw. Św. Wawrzyńca i Św. Antoniego w Borku Strzelińskim (Parish chronicle 1946-2012, parish of St Lawrence \& St Antoni in Großburg).
} 
polychrome interior designed by Joseph Dutkiewicz was painted in 1962. From the 1990s until 2019, the church underwent a series of renovation works during which the Protestant-Catholic beauty of its religious heritage was revealed. Thanks to the ecumenical attitude of the priest, Wiesław Szczęch, with the approval of the inhabitants of Borek Strzeliński, the historical and religious genesis of the temple was discovered and preserved.

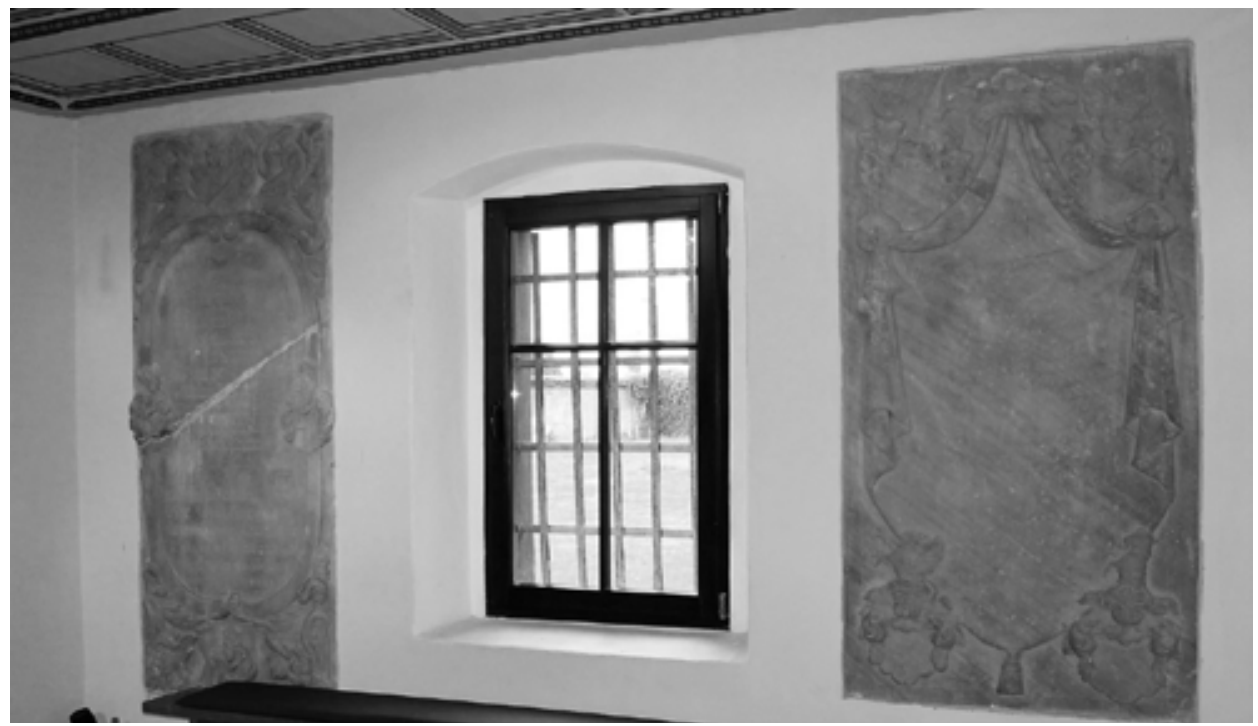

Fig. 8: Epitaphs commemorating Johann Sigmund von Kanitz (to the left) und Dallwitz and Justina Maksymiliana von Kanitz (to the right)

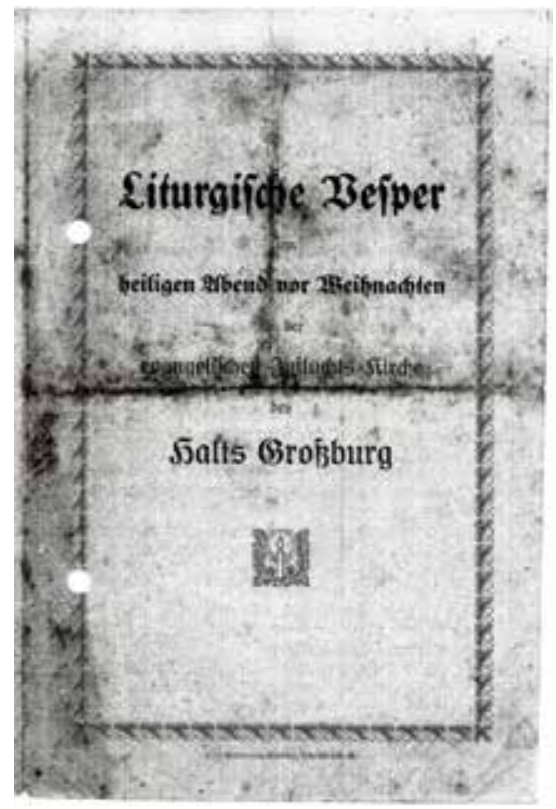

Fig. 9: Vespers for Christmas Eve at the Protestant Church of Großburg (currently Borek Strzeliński)

VI. Borek Strzeliński historical and demographical transformation

The present acceptance of Protestant heritage among the inhabitants of Borek Strzeliński is an interesting case study in relation to the settlers of this area of western Poland. Initial 
analyses of acceptance and shaping attitudes are rooted in historical, national and social conditions. In order to understand the attitudes, it was necessary to show the inhabitants the historical heritage dating back to the twelfth century as Borek was founded by the Templars in 1155 and an important event in its history was the construction of the church in 1232. In 1234 or 1237 Prince Henry the Bearded gave Borek with all its property to a bishop from Lebus in Neumark. The village, with four others, was thus transferred from Silesian administration to that of the Margraviate of Brandenburg, becoming a sort of "Brandenburg enclave" in Silesia. In 1553, the Bishop of Lebus, with the permission of margrave John of Brandenburg, gave Borek's property as a bishop's fief, for a sum of 5000 thalers, to Friedrich von Kanitz of Hohenzollern descent. ${ }^{31}$ The estate remained in the family's hands until 1745 when it came into the possession of the von Tenczins. After 51 years, in 1796, the estate returned to the von Kanitz family through Baron von Rentz. In 1843, Juliusz von Bonsdorf bought the estate, which in 1858 he sold to Georg von Schoenermark. In the same year, the son of Georg, Henryk von Schoenermark, moved in with his wife, Anna of Haessler, creating an important centre for the village's social and cultural life. In 1886, after the death of Henryk, his wife, for financial reasons, sold up to a "commercial counsellor", Ludwig Friedmann auf Grossburg whose family administered the estate. ${ }^{32}$

For Borek Strzeliński, 1945 was the year of the biggest social and economic change. At the beginning of June 1945, the estate was included under the Potsdam treaty in the resettlement process and the village became populated by inhabitants from central Poland and the Eastern border areas of Korościatyn (Ukrainian: Krynycia), Kowalówka (Ukrainian: Kowaliwka), Komarno (Ukrainian: Komorno), Monasterzyska (Ukrainian: Monastyrska) and Chłopy (Ukrainian: Peremożne). The migrants arriving in Borek Strzeliński brought with them the different cultural values, attitudes and models of behaviour shaped by their previous places of residence. They differed from one another in psychological characteristics, but often there was a mutual coming together of the varying regional groups, becoming aware of each other's existence, a sharing of cultural heritage and an assessment of their differences in the levels of development demonstrating their differing cultural and ethnic origins. ${ }^{33}$ The resettlement exemplified by Borek Strzeliński has created a heterogenous structure among its inhabitants, and this became even more varied after the opening of a state-owned farm (PGR) in the 1950s which attracted workers from the whole of Poland. An important element having an impact on the population of the village was, and still is, a national road which allowed contact with the urban areas of Wrocław, Brzeg, Oława and Strzelin, and had an impact on social and cultural development by a willingness of the inhabitants to increase their professional qualifications and socially advance. The process had an impact in the creation of a group of workers and peasantworkers with more open minds and increased education, which perhaps was, and certainly currently is, of great importance in the perception of the existence of German cultural heritage.

\footnotetext{
${ }^{31}$ See: DZIEDO, Chris. Grossburg - eine Dorfgeschichte, Unsere Deutsche Wurzeln, Heimatblatt. April 1977.

32 See: KOLAKIEWICZ Elżbieta. Katalog Zabytkón Sztuki. Wojewódz̨two Breslauskie (Dolnoślaskie), Powiat Strzeliński (Art Monuments Catalog. Breslau Voivodeship (Lower Silesia), Strzeliński Poviat). Instytut Sztuki Polskiej Akademii Nauk, Instytut Historii Sztuki Uniwersytetu Breslauskiego, Warszawa, 2008. ISBN 978-83-89101-47-1.

${ }^{33}$ See: NASZ, Adolf. Przemiany kulturowo-społeczne we wsi dolnośląskiej po drugiej wojnie światowej (Cultural and social changes in the Lower Silesian village after the Second World War) In: Prace i materialy etnologiczne, tom XX, Wrocław, 1970, pp. 9-52.
} 
J. Lach et al.: The role of the Protestant legacy in shaping Lower Silesian cultural heritage as exemplified...

\section{Protestant legacy and its perception among Borek Strzeliński inhabitants}

Against the background of the above complex structure of the history of the village and its inhabitants, the role of the sacred in the contemporary landscape of Borek Strzeliński, as an important element shaping identity and social attitudes, can be considered. The church with its sacred ${ }^{34}$ zone is an important, visible "matrix" of the material heritage of the village. In the case study of the church in Borek Strzeliński, an important element in the emergence of a specific cultural and religious heritage is the specific conditions of ownership autonomy of former landowners, e.g. the family of Frederick von Kanitz. These conditions influenced the evolution of the rituals and sacralisation of space through the adaptation of the existing temple, determining the individual features of the style and function of the church until 1945-7. In these years, German symbolism in the landscape of Borek Strzeliński was masked by painting, plastering over or completely removing names and symbols. Examples include the liquidated church graveyard and the removal of epitaphs from the church wall and inside the church and of inscriptions on houses, public utility buildings and monuments. In the last example, the original content has been replaced with new content or even given a different function (Fig. 10).

Analysis has indicated that the only post-German symbol saved within the village is the Protestant heritage enclosed within the contemporary area of the sacrum of St Lawrence \& St Anthony's Church whose location has been unchanged since the thirteenth century. The church is in the centre of the village and neighbours a palace and residential and commercial buildings. It is 200 metres from the main artery, a historical road from north to south. The church, together with its surroundings, is an element of a close-knit rural architecture, with the palace park to its north-east. The location of the church has remained unchanged since its erection and its dominant role in the landscape is still noticeable. The building is distinguished by its spatial form, architectural decor and the symbolism of a cross. Despite the fact that in the 1950s the village increased its size two-fold (in the north with four-storey blocks of flats, to the north-east single-family houses, and an industrial area with low warehouses to the west), the church has maintained its dominant role (Fig. 11).

The Protestant legacy is found within the architectural detail, sculpture and paintings of the church, the church wall and the presbytery. Currently, thanks to the church authorities and the local priest, Wiesław Szczech, the church is undergoing general renovation, during which elements of the Evangelical symbolism both inside and outside are being uncovered and renovated (Fig. 12).

\footnotetext{
${ }^{34}$ Sacrum, i.e. a sacred place that inhabitants respect and identify with, in an architecture that differs from the residential and commercial surroundings and creating a so-called sacred landscape. It constitutes an element of geographic space whose structure and function are determined by the interaction between the evolution and functional processes of nature and culture that decide its physiognomic uniqueness (Eliade 1993, Jones 2003, Myga-Piątek 2012). These are the landscapes of places characterised by uniqueness and originality, spaces for meditation and reflection - sacred places (Jackowski 2003). In her studies of the typology of sacred landscapes, Myga-Piatek (2012) points to several cognitive areas which involve a material (real) aspect where an important issue is to analyse the location of churches within a town's panorama. The semiotic aspect enabling an analysis of the importance of the existence of sacrum within a certain area, and an aesthetic aspect whose functioning affects the phenomenon of hierophany. The studies of Plit (2008) must be mentioned when referring to the historical determinants of the creation of sacred landscapes with an Evangelical element that enables the existence of the "refuge" churches in the current Lower Silesia to be defined. He states that the forming of sacred landscapes has been affected throughout history by geopolitical changes leading to the identification of specific religious and cultural civilisations, and influenced by the natural environment.
} 

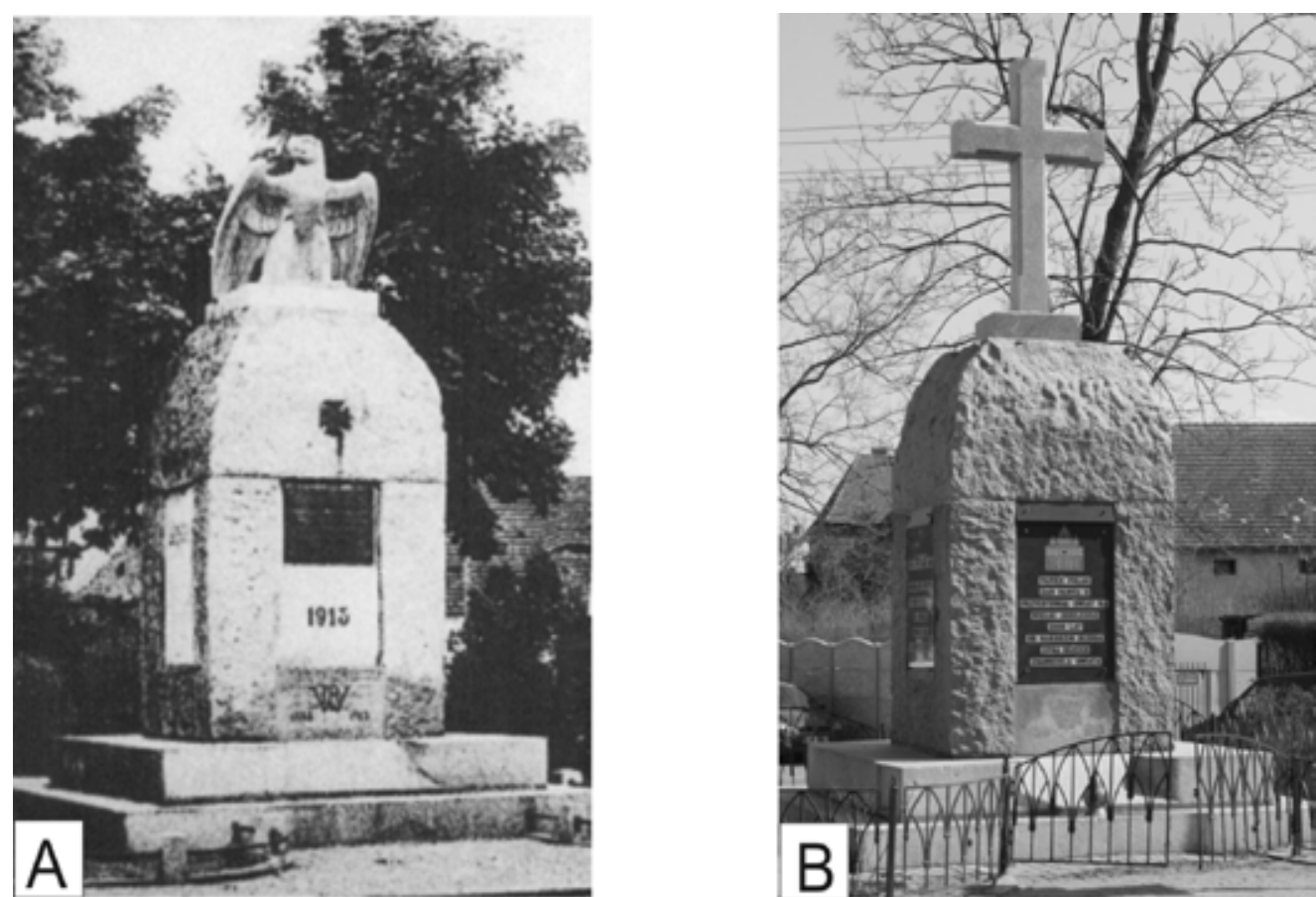

Fig. 10: An example of the changing of the designation of a monument in the centre of Borek Strzelinski-A) a monument to the victims of World War I, around 1920 (Kołaczkiewicz 2008): archival Fig.; B) a modern monument to the 770th anniversary of the church in Borek Strzeliński, 2007, to Pope John Paul II for preparing the world for the Great Jubilee of 2000 years of Christianity, and to the 1000th Anniversary of the Wrocław Archdiocese in 2000

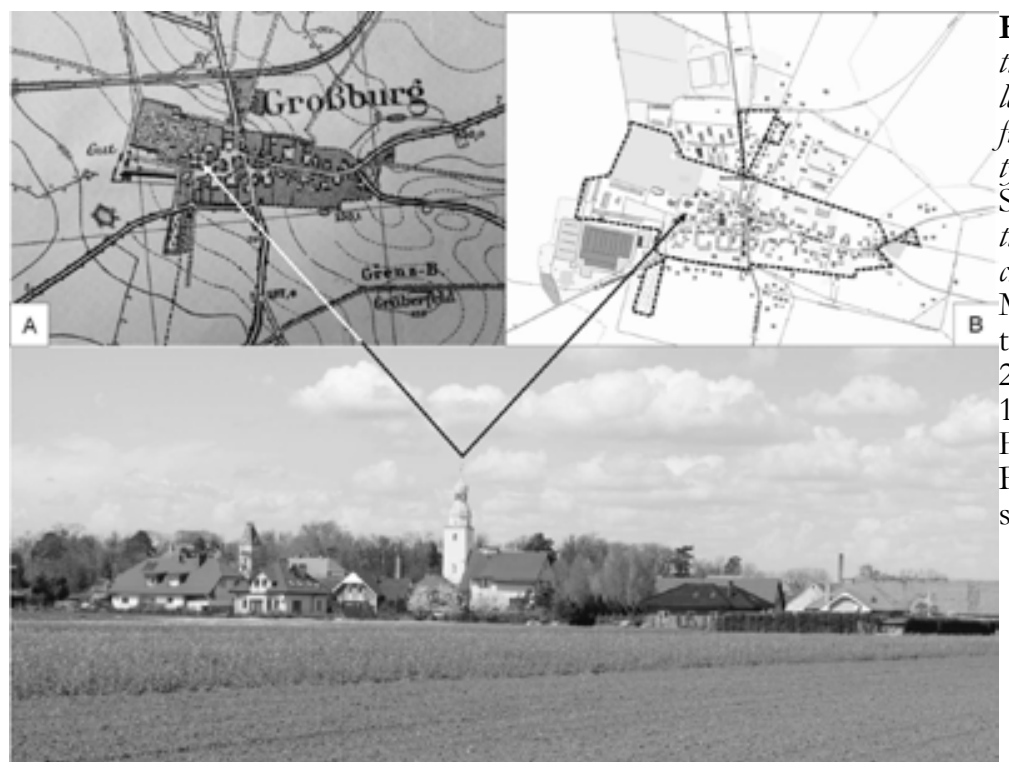

Fig. 11: The church has been the dominant building in the landscape of Borek Strzelinski from the nineteenth to twenty-first centuries

Source: Map A - Messtischblatt kartenblatt Wäldchen, Breslau 1885;

- Map B - Mapa topograficzna ukl.1992, 1: 25 000, Borek Strzeliński, 1992.

Fig.graph: a panorama of Borek Strzeliński, looking south, 2017

In the interior, the renovation has uncovered the beauty of the polychrome with its religious elements on the choir galleries, the sculpture and ornament on the pulpit, the epitaphs in the entrance hall, the portals with important inscriptions on the keystones and the beauty of the 
coffered ceiling with the date of its construction (1702) uncovered during the work. On the exterior, memorials with original German inscriptions were uncovered and restored (Fig. 12), two epitaphs were restored on the church walls, while the wall of the former graveyard was renovated with the epitaphs and gravestones recovered being transformed into a lapidarium (Fig. 13). The few remaining monuments are treated with care and commemorated; for example, on November 1, All Saint's Day, candles are lit there (Fig. 14).

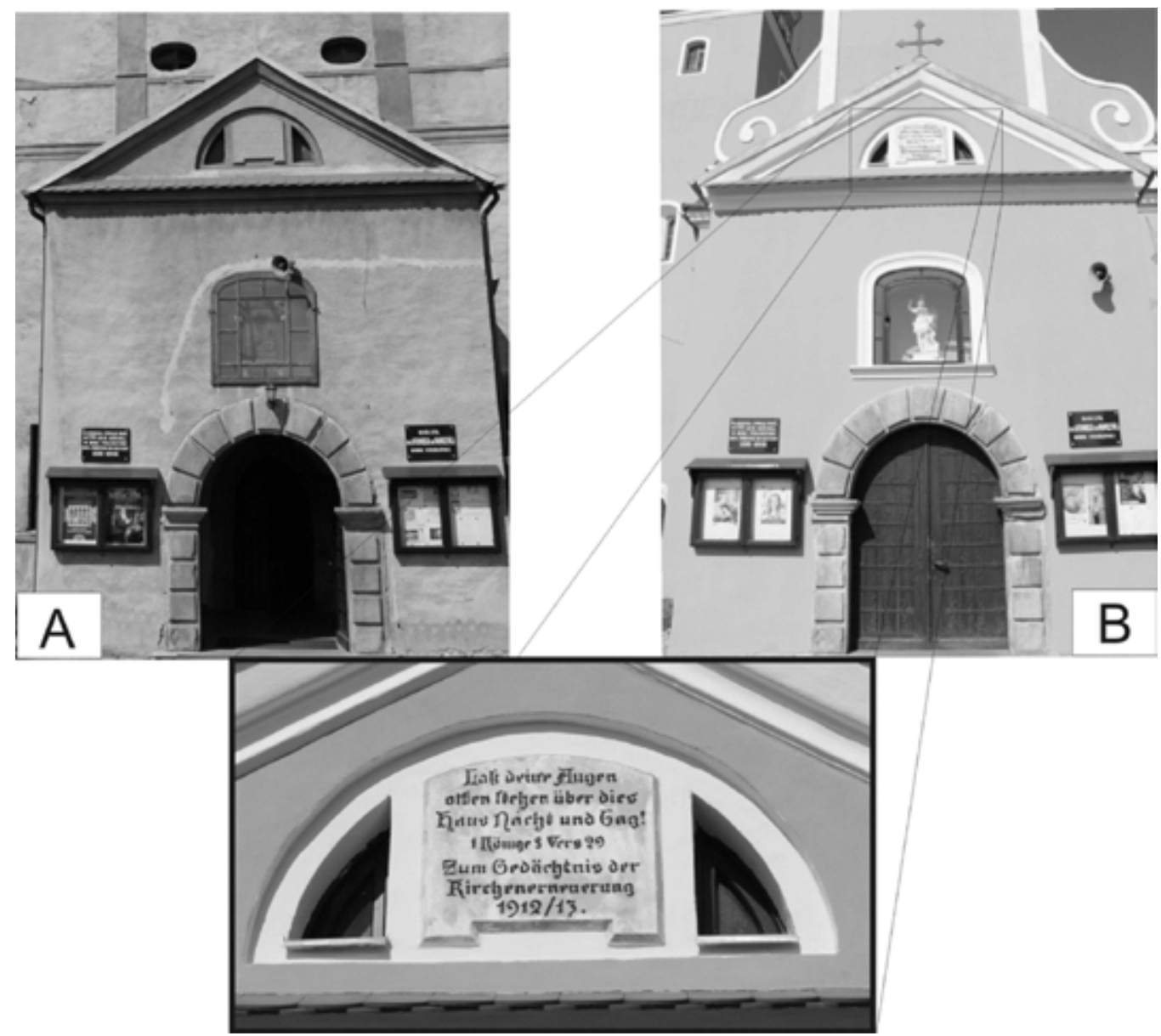

Fig. 12: An example of the ecumenical approach towards the church building of Borek Strzelinski: restored original text

Source: J. Łach - A) entrance from the southern transept 2013; B) renovated entrance of the southern transept, 2018

In the process of restoring the architectural beauty of the church and its surroundings, it is significant to focus attention on the origin and authenticity of the Evangelical elements supervised by a conservator-restorer and, importantly, accepted by the local people. An analysis of the acceptance of Protestant heritage according to age among Borek Strzeliński's inhabitants, to show trends of behaviour towards the local cultural heritage, is extremely difficult due to the lack of openness of the inhabitants, especially the elderly. However, the influence of the 
elite has made it possible to establish communication that could reveal current attitudes and require in-depth academic research, mainly sociological. Concerning the acceptance of the post-German heritage, it should be emphasised that this process, which has been going on since the 1989/1990 system changes, is extremely difficult, as the earlier ideological approach

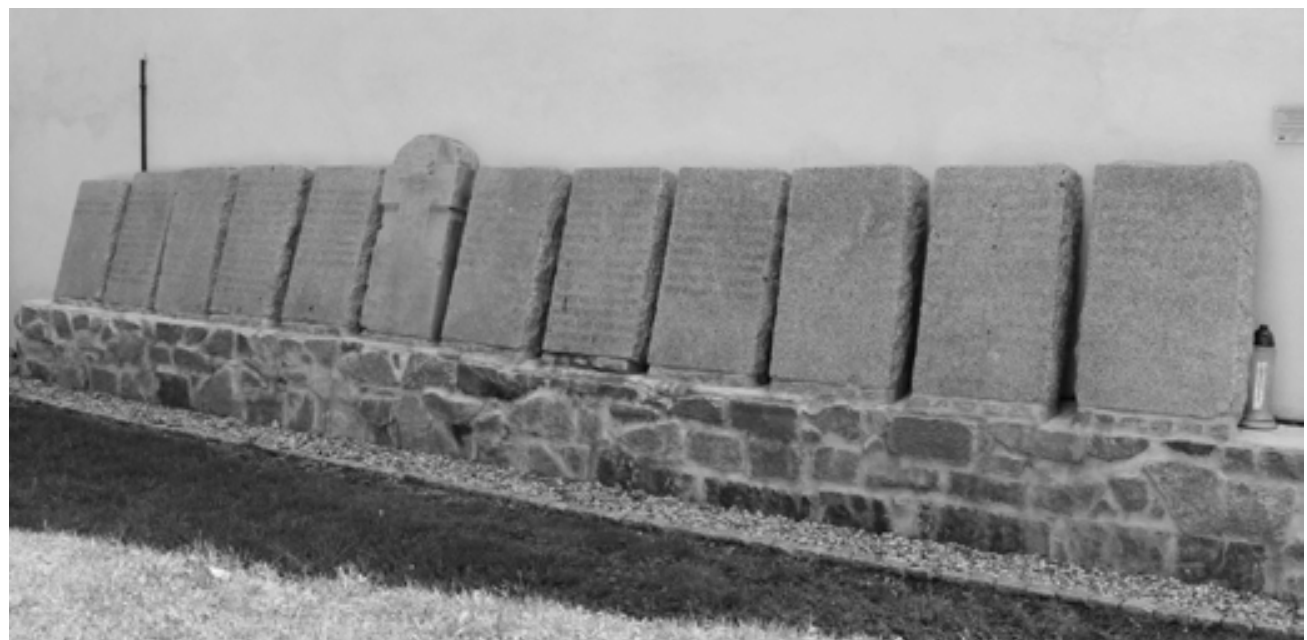

Fig. 13: The church lapidarium created after the renovation of the former graveyard with maintained gravestones: condition in 2019

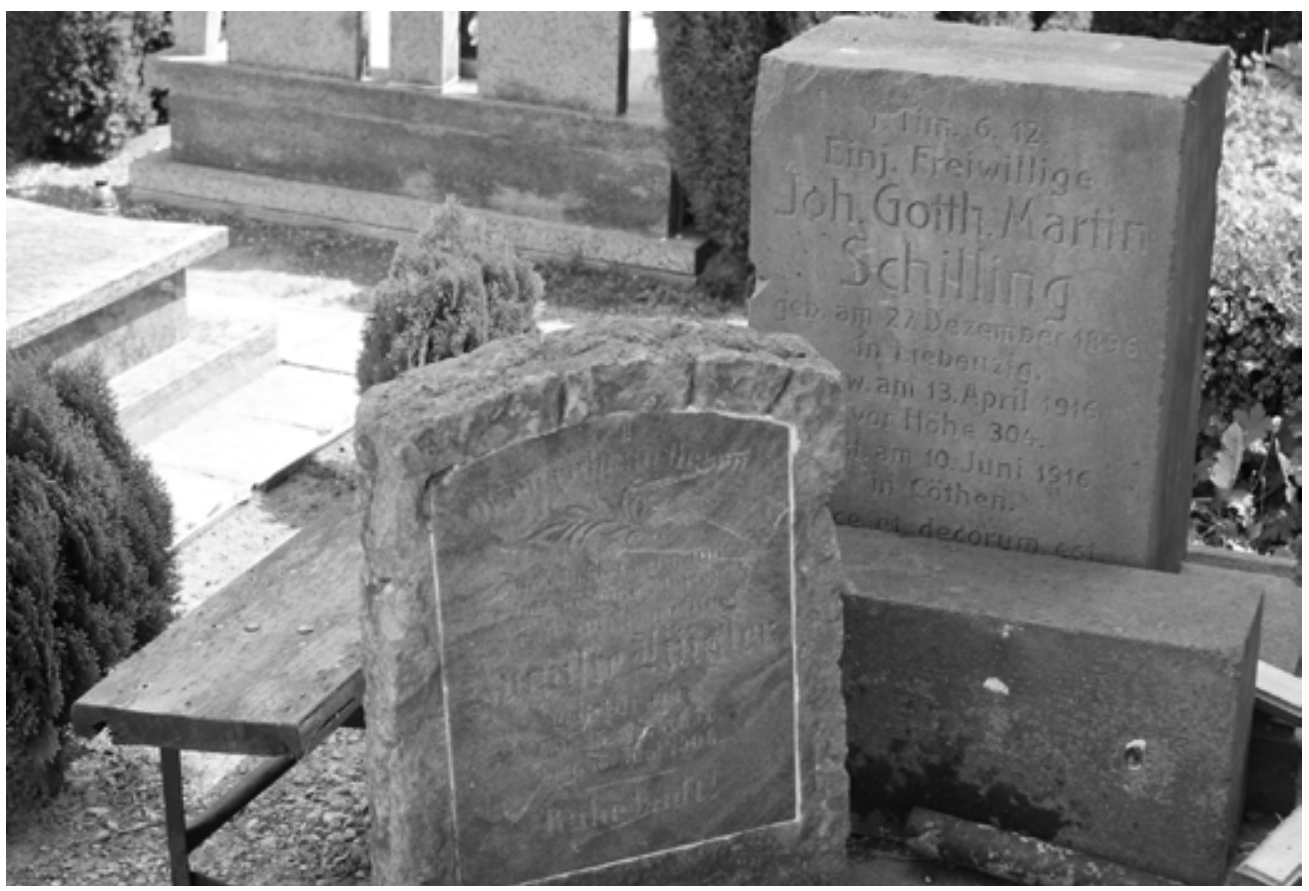

Fig. 14: Graveyard lapidarium - material memory of a former inbabitant of Borek Strzelinski

of the Polish People's Republic authorities caused irreversible social and cultural damage in the Recovered Territories 
J. Lach et al.: The role of the Protestant legacy in shaping Lower Silesian cultural heritage as exemplified...

The de-Germanisation process lasted until the systemic transformation in 1989/1990, causing significant damage to the former culture and society within the "Recovered Territories", although it is not possible to legally (by means of statute) eliminate the richest source of cultural and artistic tradition, i.e. erase the historical truth. ${ }^{35}$ More openness and a broader awareness of the problems of the surrounding world, together with social attitudes, have made Poles aware that there is a moral and political problem with attitudes towards the German cultural heritage. It is now being noticed that the process of removing all traces of a foreign culture was a political mistake and a cultural "sin". ${ }^{36}$ Using the example of the inhabitants of Borek Strzeliński, it might be stated that the current approach towards the German material legacy visible in the village landscape is neutral, as most of the material traces were destroyed in the 1940s and 50s. Only 3\% of respondents indicated that the church, the graveyard and the monument were symbols related to German culture. During the survey, the inhabitants were asked about their knowledge of the Evangelical legacy. The majority demonstrated a full awareness: as many as $78 \%$ of them are aware of its existence but $22 \%$ are not. Such an answer was given by respondents with a low economic status, not aspiring to higher standards of life and, it is worth mentioning, among new inhabitants from outside Borek Strzeliński, living in new houses within the village, who have no need for historical or geographical assimilation. They treat their new home as a "sleeping facility" and place of rest, since they spend the majority of their time working in the Wrocław agglomeration. Within the $78 \%$ declaring the existence of a Protestant cultural element, as many as 65\% treat it neutrally, and $23 \%$ declare that they are happy that elements of Protestant culture are exposed in the sacred space through smallscale architecture, paintings, sculpture and inscriptions. These are mainly second-generation inhabitants working in administration, education, services (mostly university graduates) and people working in agriculture (wealthy farmers). This group also includes adolescents (third generation) who care about understanding the region, their "Little Homeland", with the help of their teachers. Only 12\% think that uncovering and exposing Protestant elements is not needed, and raise fears about a come-back of "the Germans", which in today's circumstances of free movement of citizens in the European Union, is seen as a threat. This is the attitude of the oldest residents (former pioneer settlers).

The renovation of the church and the surrounding areas, the presbytery and the graveyard carried out since the beginning of the twenty-first century by the local parish (the renovation was completed in 2019) uncovered the architectural and historical beauty of the sacred space and made local people aware of the existence of elements related to Protestant religious functions whose visual, historical and religious value has now been widely accepted.

\footnotetext{
${ }^{35}$ See: LIPSKI Jan, Józef. Wir mussen uns alles sagen...Essays zur deutch-polnischen Nachbarschaft, [Powiedzieć sobie wszystko...Eseje o sąsiedztwie polsko-niemieckim]. Wyd. Polsko-Niemieckie, Gliwice-Warszawa, 1996. ISBN: 83-86653-02-7.

36 See: ZYBURA, Marek. Polacy wobec niemieckiego dziedzictwa kulturowego na Dolnym Śląsku (Poles and German cultural heritage in Lower Silesia). In: B. Cybulski (ed.), Dolny Ślask 1945 - Dolny Ślask 2005. Stowarzyszenie na Rzecz Promocji Dolnego Śląska, Wrocław, 2006, pp. 257-271. ISBN 8392325508.
} 
Through publications of a popularising nature, ${ }^{37}$ the inhabitants have been made aware of the historical, architectural and academic value of the church, which has become the pride of the village. It is worth pointing out the educational role and the important part that has been played by the local priest, Wiesław Szczęch; his ecumenical attitude has contributed widely to the acceptance and protection of the Protestant elements. Also, those responsible for the education and upbringing of young people in Borek Strzeliński (teachers and librarians) are aware how much the historical and geographical value of the church can contribute to teaching about the distant history of the village and of the church itself by organising competitions for posters and albums, as well as for knowledge about the so-called "Little Homeland". Some of the inhabitants demonstrate their interest in the history of the village and of the church on social media, gathering archive figures or drawings. Because of such interest, the question can be posed whether the Evangelical heritage has any impact on the identity of the inhabitants. As many as $97 \%$ answered "yes, we are proud to have an exceptional sacred building", a refuge church with specific Protestant decoration as well as its historical value; just 3\% could not tell whether history or cultural heritage had any impact on their lives, again mostly those who had moved in just recently. What will the future perception of the Evangelical heritage be? The inhabitants were asked whether the Evangelical legacy should be searched for and exposed in the landscape of the village? The answer was "rather yes" (52\%), 37\% responding with a definite "yes", as this increases the historical and geographical value of the village, but 11\% responding "no", saying that there are no financial resources and there is no social motivation. The "no" argument was most frequently found among elderly inhabitants. An important aspect of the survey is the strong awareness of the existence of an Evangelical heritage because of its value as protected by society, and proven by donations for the renovation of sacred buildings in Borek Strzeliński.

\section{Conclusion}

The church in Borek Strzeliński is undoubtedly a unique sacrum of Catholic-Protestant origin, influencing the complex historical identity of the city and its inhabitants. Despite the passage of time, this site has become an inseparable element of the countryside and its surroundings, combining the cultural and landscape value of this area. The visual architectural symbols in the church largely identify the ecumenical sacred space, accepted and cared for by the inhabitants. The research highlights problems of resettlement and the cultural and religious heritage left behind, as well as its acceptance by new residents. This difficult topic covers social aspects and the sphere of the sacred place. According to the authors, presenting this issue using the example of the Evangelical Church from the sixteenth-seventeenth centuries in Borek Strzelinski allows the exploration not only of the previously unknown history of this temple, but also its religious changes, which were and are an important phenomenon in the Lower Silesia region of Poland. The fate of Poles and the German minority are intertwined here, showing the essence of the common historical and architectural heritage on the church and in landscape

\footnotetext{
${ }^{37}$ See: LACH Janusz. 780-lat obecności kościoła pw. Św. Wawrzyńca i Św. Antoniego w Borku Strzelińskim (780 years of the existence of the church of St Lawrence \& St Anthony in Borek Strzelińsk), Wyd. Parafia Rzymskokatolicka w Borku Strzelińskim, Großburg, 2012a; and LACH Janusz (2012b). Symbolika kultury materialnej wsi dolnośląskiej na przykładzie Borka Strzelińskiego, jej wartość i zmiany (Symbolism of material culture of the Lower Silesian village based on the example of Großburg, its values and changes). In: Lach, J., Zaręba, A. (eds), Studia krajobrazowe, Krajobrazy zdefiniowane - znaki i symbole w krajobrazie. Wyd. Zakład Geografii Regionalnej i Turystyki, Uniwersytet Breslauski, Breslau, 2012, pp. 181-196. ISBN 978-83-62673-14-8.
} 
changes. This article, it seems, demonstrates the first and at the same time most important and interesting trace of the Protestant heritage left in Lower Silesia. The refuge church is set against the background of the history of the inhabitants of Borek Strzeliński. An important element that allowed this monument to survive was social acceptance and the lack of destruction of the Protestant heritage in both the sacred and architectural spheres. What is more, the research showed that the results of the balanced civic attitudes of the residents, as well as the action taken to gain and expand understanding of the "Little Homeland" which led to the protection of the monument and thus the legacy of its former residents, in the era of a consumer lifestyle can be safely considered undoubtedly as extremely positive. The inhabitants of Borek Strzeliński, despite the difficult 74-year period of building their own identity on the so-called "Recovered Territories", have accepted the post-German and Protestant cultural heritage which is deeply rooted in the regional identity of Lower Silesia. Currently, Poles living in these lands present their cultural heritage through the elite of social life: priests, librarians, teachers and, above all, people with a passion for sightseeing and learning and disseminating history. There are more and more reconstruction projects related to the celebration of various historical, religious and folk events, in which not only the local community but also the descendants of former residents can participate. This gives the opportunity to increase awareness and tighten bonds. Moreover, the undeniable fact and the driving force behind the development is that the awareness of the inhabitants allows for a better protection of the multicultural heritage of the region.

According to the authors, the advantage of the research presented here is the collection of exceptional historical data from the former German culture, and the first Polish settlers who came to these areas after 1945 to start a new stage of their life in a new reality and a new cultural landscape. Thanks to the research, it will be possible to carry out further landscape analyses in Borek Strzeliński which will increase awareness of the existing socio-cultural interdependencies in Lower Silesia and show their multidimensionality. In the course of the research there was also a clear indication of the value of in-depth historical and sociological research concerning the village which, according to the authors, could constitute an interesting development of the topic discussed here. In addition, there is a request to undertake in-depth historical and sociological studies, similar to those on the Upper Silesia region, ${ }^{38}$ but for socially and ethnically different reasons.

\section{References}

AHONEN, Pertti (2014). On Forced Migrations: Transnational Realities and National Narratives in Post-1954 (West) Germany. In: German History, Vol. 32, No. 4, pp. 599-614. ISSN 0266-3554.

BANAŚ, Paweł (1971). Studia nad śląską architektura protestancką II połowy XVII wieku (Studies on Silesian Protestant architecture of the second half of the 17th century). Roczniki sztuki Śląskiej. Muzeum Narodowe we Breslauiu, Breslau, 7, pp. 46-51. ISSN 0557-2231.

\footnotetext{
${ }^{38}$ See: KARCH, Brendan. Nation and loyalty in a German-Polish Borderland: Upper Silesia, 1848-1960. German Historical Institute Washington, D.C., and Cambridge University, 2018. ISBN: 978-1-108-48710-8; and BJORK, James. Neither German nor Pole: Catholicism and National Indifference in a Central European Borderland. University of Michigan. ISBN-10: 0472116460; and KAMUSELLA, Tomasz (2006). Silesia and Central European Nationalisms: The Emergence of National and Ethnic Groups in Prussian Silesia and Austrian Silesia, 1848-1918 (Central European Studies). Purdue University, 2008. ISBN-10: 1557533717.
} 
BJORK, James (2008) Neither German nor Pole: Catholicism and National Indifference in a Central European Borderland. University of Michigan. ISBN-10: 0472116460.

BJORK, James, GERWATH, Robert (2007). The Annaberg as a German-Polish Lieu de Mémoire. In: German History, Volume 25, Issue 3, July 2007, pp. 372-400.

BRUBAKER, Rogers, COOPER, Frederick (2000). Beyond "identity". In: Theory and Society, Vol. 29, Issue: 1, pp. 1-47. ISSN 0304-2421.

BUKRABA-RYLSKA, Izabella (2011). Dziedzictwo kulturowe jako czynnik rozwoju obszarów wiejskich. In: Nurzyńska, I., Drygas, M. (eds), Rozwój obszarów wiejskich w Polsce. Diagnozy, strategie, koncepcje polityki. Warszawa, IRWiR PAN, pp. 219-238. ISBN 8389900-45-9.

CZAPLIŃSKI, Marek (2007) Dzieje Śląska od 1806 do 1945 r. In: Czapliński M. (ed.), Historia Śląska. Acta Universitatis Wratislaviensis, 3008, Wrocław, s. 278-467. ISBN: 978-83-2292872-1.

CZARNUCH, Zbigniew (1997). Oswajanie krajobrazu. Polscy osadnicy w dorzeczu dolnej Warty (Taming the landscape. Polish settlers in the Lower Warta basin). In: Mazur Z.(ed.), Wokół niemieckiego dziedzictwa kulturowego na Ziemiach Północnych i Zachodnich. Wyd. Instytutu Zachodniego, Poznań, pp. 169-190. ISBN 83-85003-87-8.

DOBRZYNIECKI, Aneta, et al. (2008). Powiat Strzeliński - Großburg (Poviat of Strzeliński - Großburg). In: Katalog Zabytów Sztuki Województwo Breslauskie (Dolnośląskie (edit.) E. Kołaczkiewicz,). Wyd. Instytut Sztuki PAN Instytut Historii Sztuki Uniwersytetu Breslauskiego, Warszawa, pp. 9-19 ISBN 978-83-89101-47-1.

DZIEDO, Chris, (1977). Grossburg - eine Dorfgeschichte, Unsere Deutsche Wurzeln, Heimatblatt, April 1977.

ELIADE, Mircea (1996). Sacrum i profanum. O istocie religijności (Sacrum and profanum: about the essence of religiosity). Wyd. KR, Warszawa. ISBN 978-83-628-5825-5.

GIBSKI, Damian (n.d.). Karta ewidencyjna zabytku architektury i budownictwa WOSOZ we Breslauiu ('Identification card' of the WOSOZ architectural and building monument in Breslau,

GOLIŃSKI, Mateusz, HARC, Lucyna, MAROŃ, Jerzy, WISZEWSKI, Przemysław (2006). Dolny Śląsk w latach 1526-1805 (Lower Silesia in the years 1526-1805). In: W. Wrzesiński (ed.), Dolny Śląsk - monografia historyczna. Wyd. Uniwersytetu Breslauskiego, Breslau, pp. 261-296. ISBN: 83229-2763-0.

GORZELIK, Jerzy (2018). Konsekwencje wojny trzydziestoletniej dla protestanckiego dziedzictwa artystycznego na Górnym Śląsku. In: Joachim Bahlcke, Wacław Gojniczek, Ryszard Kaczmarek (eds), Dziedzictwo górnośląskiej reformacji. Wpływ protestantyzmu na politykę, społeczeństwo i kulturę w wiekach XVI-XX. Katowice: Instytut Badań Regionalnych w Katowicach.

GRUK, Wojciech (2015). Silesian Churches of Peace and the Royal Hungarian Articular Churches: Possible Legal and Architectural Relations. In: Protestantischer Kirchenbau der Frühen Neuzeit in Europa. Grundlagen und neue Forschungskonzepte. — Protestant Church Architecture in Early Modern Europe: Fundamentals and New Research Approaches. Regensburg 2015, pp. 333-343. ISBN 978-3-7954-2942-3.

GRUNDMANN, Gunter (1970). Der Evangelische Kirchenbau in Schlesien. Verlog Wolfgang Weidlich. Frankfurt am Main. 
J. Lach et al.: The role of the Protestant legacy in shaping Lower Silesian cultural heritage as exemplified...

HARASIMOWICZ, Jan (2000). Die Kunst der Reformationszeit als gemeinsames Kulturerbe an der mittleren Oder und unteren Warthe. In: Krystyna Gabryjelska and Ulrich Knefelkamp (eds), Brückenschläge. Kulturwissenschaften in Frankfurt (Oder) und Breslau. Vorträge der ersten gemeinsamen Ringvorlesung der Europa-Universität Viadrina Frankfurt (Oder) und der Universität Breslau. Berlin: scripvaz-Verlag Christof Krauskopf 2000, pp. 31-45. ISBN 3931278131.

HARASIMOWICZ, Jan (2008). Die Altranstädter Konvention und die Kunstlandschaft Schlesiens. In: Jürgen Wolf (ed.), 1707-2007 Altranstädter Konvention: Ein Meilenstein religiöser Toleranz in Europa. Halle (Saale): Sächsisches Staatsarchiv in Kommission bei mdv Mitteldeutscher Verlag 2008 (Veröffentlichungen des Sächsischen Staatsarchivs, Reihe A: Archivverzeichnisse, Editionen und Fachbeiträge, Bd. 10), pp. 133-157. ISBN 978-389812-587-1.

HARRISON, Edward D. R. (1997). Lower Silesia from Nazi Germany to Communist Poland, 1942-49. In: German History, Volume 15, Issue 1, January 1997, pp. 170-171. ISSN 02663554.

JACKOWSKI, Antoni (2003). Święta przestrzeń świata. Podstawy geografii religii (Sacred space of the world: the basics of the geography of religion). Uniwersytet Jagielloński, Kraków. ISBN 83-233-1717-8.

JAKUBOWICZ, Zbigniew (1997). Osobliwości pogranicza Ziemi Oławskiej - Kościół ucieczkowy w Borku Strzelińskim (Singularities of the Oławska borderland - the refuge church in Großburg). Wiadomości Oławskie, p. 15, 11.09.1997.

JONES, Michael (2003). The concept of cultural landscape: discourse and narratives. In: Palang, H., Fry, G. (eds), Landscape Interfaces: cultural heritage in changing landscapes vol 1. Springer, Dordrecht, pp. 21-51. 978-90-481-6348-9.

JUREK, Piotr (2006). Osadnicy polscy w latach 1945-1947 (Polish settlers in 1945-1947). In: B. Cybulski (ed.), Dolny Śląsk 1945 - Dolny Śląsk 2005. Stowarzyszenie na Rzecz Promocji Dolnego Śląska, Breslau, pp. 82-90. ISBN 8392325508.

KALINOWSKI, Konstanty (2006). Barock in Schlesien. München 1990. ISBN 3-422-06047.

KAMUSELLA, Tomasz (2006). Silesia and Central European Nationalisms: The Emergence of National and Ethnic Groups in Prussian Silesia and Austrian Silesia, 1848-1918 (Central European Studies). Purdue University. ISBN-10 : 1557533717.

KARCH, Brendan (2014). Germans to Poles: Communism, Nationalism, and Ethnic Cleansing after the Second World War. In: German History, Volume 32, Issue 2, June 2014, pp. 334 336. ISBN: 1107671485

KARCH, Brendan (2018). Nation and loyalty in a German-Polish Borderland: Upper Silesia, 1848-1960. German Historical Institute Washington, D.C., and Cambridge University. ISBN: 978-1-108-48710-8.

Karte A. "Das Evangelisch Schlesien in Folge der Altranstadtilchen Convention", 1707, author Edward Anders. In: Historischer Atlas der Evangelischen Kirchen in Schlesien. Er. Glogau, 1845.

Karte B. Messtischblatt kartenblatt Wäldchen. Breslau, 1885.

KO\&AKIEWICZ, Elżbieta (2008). Katalog Zabytków Sztuki. Województwo Breslauskie (Dolnośląskie), Powiat Strzeliński (Art Monuments Catalog. Breslau Voivodeship (Lower Silesia), Strzeliński Poviat). Instytut Sztuki Polskiej Akademii Nauk, Instytut Historii Sztuki Uniwersytetu Breslauskiego, Warszawa. ISBN 978-83-89101-47-1. 
KOLAKIEWICZ, Elżbieta (2008). Katalog Zabytków Sztuki. Województwo Breslauskie (Dolnośląskie), Powiat Strzeliński (Art Monuments Catalog. Breslau Voivodeship (Lower Silesia), Strzeliński Poviat). Instytut Sztuki Polskiej Akademii Nauk, Instytut Historii Sztuki Uniwersytetu Breslauskiego, Warszawa. ISBN 978-83-89101-47-1

Kronika parafialna 1946-2012, Parafia pw. Św. Wawrzyńca i Św. Antoniego w Borku Strzelińskim (Parish chronicle 1946-2012, parish of St Lawrence \& St Antoni in Großburg).

ŁACH, Janusz (2012a). 780-lat obecności kościoła pw. Św. Wawrzyńca i Św. Antoniego w Borku Strzelińskim (780 years of the existence of the church of St Lawrence \& St Anthony in Borek Strzelińsk). Wyd. Parafia Rzymskokatolicka w Borku Strzelińskim, Großburg.

ŁACH, Janusz (2012b). Symbolika kultury materialnej wsi dolnośląskiej na przykładzie Borka Strzelińskiego, jej wartość i zmiany (Symbolism of material culture of the Lower Silesian village based on the example of Großburg, its values and changes). In: Lach J., Zaręba A. (eds), Studia krajobrazowe, Krajobrazy zdefiniowane - znaki i symbole w krajobrazie. Wyd. Zakład Geografii Regionalnej i Turystyki, Uniwersytet Breslauski, Breslau, p 181-196. ISBN 978-83-62673-14-8.

LAMONT, Michèle, MOLNAR, Virág (2002). The study of boundaries in the social sciences. In: Annual Review of Sociology, Vol. 28, pp. 167-195. ISSN 0360-0572.

LIPSKI, Jan, Józef (1996). Wir mussen uns alles sagen...Essays zur deutch-polnischen Nachbarschaft [Powiedzieć sobie wszystko...Eseje o sąsiedztwie polsko-niemieckim]. Wyd. Polsko-Niemieckie, Gliwice-Warszawa, ISBN: 83-86653-02-7.

MAZUR, Zbigniew (2003). Das deutsche Kulturerbe in den polnischen West und Nordgebieten (Studien der Forschungsstelle Ostmitteleuropa an der Universität Dortmund, Band 34). Wiesbaden, Harrassowitz Verlag. ISBN: 9783447048002.

MYCZKOWSKI, Zbigniew (2015). Kompozycyjne i architektoniczne wyznaczniki tożsamości krajobrazów (Compositional and architectural determinants of landscape identity). In: Problemy Ekologii Krajobrazu, XL, pp. 199-208. ISSN: 1899-3850.

MYGA-PIACTEK, Urszula (2012). Sacred and religious landscapes - an attempt of classification in the typology of cultural landscapes. In: Sacrum w krajobrazie. Prace Komisji Krajobrazu Kulturowego nr 17, pp. 13-23. ISSN: 1896-1460.

NASZ, Adolf (1970). Przemiany kulturowo-społeczne we wsi dolnośląskiej po drugiej wojnie światowej (Cultural and social changes in the Lower Silesian village after the Second World War) In: Prace i materiały etnologiczne, tom XX, Wrocław, pp. 9-52.

PARUSHEV, Parush, PILLI, Toivo (2004). Protestantism in Eastern Europe to the Present Day. In: Alister E. McGrath, Darren C. Marks (eds), The Blackwell Companion to Protestantism. Blackwell Publishing Ltd, pp. 155-160.

PLIT, Joanna (2016). Krajobrazy kulturowe Polski i ich przemiany (Polish cultural landscapes and their transformations). In: Prace Geograficzne Nr. 253, Warszawa.

POPIOŁEK, Kazimierz (1984). Historia Śląska od pradziejów do 1945 roku. Śląski Instytut Naukowy. ISBN 83-216-0151-0.

RYRIE, Alec (2017). Protestants: The Faith That Made the Modern World. Viking (April 4, 2017). ISBN 14051574619781405157469.

SAM, David, BERRY, John (2010). Acculturation: When Individuals and Groups of Different Cultural Backgrounds Meet. Perspectives on Psychological Science, Vol. 5, Issue: 4, pp. 472-481. ISSN: 17456916. 
STĘPIŃSKA, Maria (2002). Dokumentacja konserwatorska malowideł drewnianego stropu kościoła p.w. Św. Św. Wawrzyńca i Antoniego w Borku Strzelińskim (Conservation documentation on the paintings on the wooden ceiling of the church of Sts Wawrzyniec \& Antoni in Großburg), Number inv. 9/02, Brzeg.

SZCZEPANKIEWICZ-BATTEK, Joanna (2015a). Auf den spuren der Bomischen und Mahrischen bruder in Polen. Konsystosz Kościoła Ewangelicko-Reformowanego w RP, Warszawa.

SZCZEPANKIEWICZ-BATTEK, Joanna (2015b). Kościoły graniczne i ucieczkowe w krajobrazie kulturowym pogranicza śląsko-łużyckiego i ziemi legnickiej (Border and refuge churches in the cultural landscape of the Silesian-Lusatian borderland and the Legnica region). In: Studia z Geografii Politycznej i Historycznejm, vol.4, pp. 291-311. ISSN 24500127.

ZYBURA, Marek (2005). Der Umgang mit dem deutschen Kulturerbe in Schlesien nach 1945. Senfkorn-Verlag Theisen, Görlitz. ISBN 3-935330-19-7.

ZYBURA, Marek (2006). Polacy wobec niemieckiego dziedzictwa kulturowego na Dolnym Śląsku (Poles and German cultural heritage in Lower Silesia). In: B. Cybulski (ed.), Dolny Śląsk 1945 - Dolny Śląsk 2005. Stowarzyszenie na Rzecz Promocji Dolnego Śląska, Breslau, pp. 257-271 ISBN 8392325508. 